J. Mol. Catal. A: Chem., 2008

\title{
Hydroformylation of oct-1-ene catalyzed by dinuclear gem- dithiolato-bridged rhodium(I) complexes and phosphorus donor ligands
}

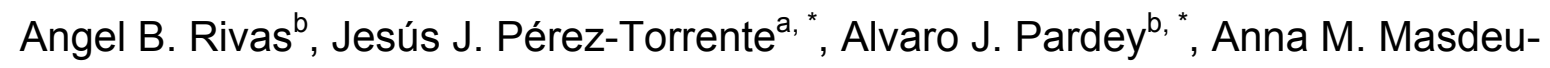
Bultóc $^{c}$, Montserrat Diéguez ${ }^{c}$ and Luis A. Oro ${ }^{a}$

${ }^{a}$ Departamento de Química Inorgánica, Instituto Universitario de Catálisis Homogénea, Instituto de Ciencia de Materiales de Aragón, Universidad de ZaragozaC.S.I.C., 50009-Zaragoza, Spain.

${ }^{b}$ Centro de Equilibrios en Solución, Escuela de Química, Facultad de Ciencias, Universidad Central de Venezuela, Caracas, Venezuela.

${ }^{c}$ Departament de Química Física i Inorgànica, Universitat Rovira i Virgili, Marcel/lí Domingo s/n, 43007-Tarragona, Spain

"Corresponding author. Fax: +34 976761143. E-mail: perez@unizar.es, alvaro.pardey@ciens.ucv.ve 


\section{Abstract}

The dinuclear gem-dithiolato bridged compounds $\left[\mathrm{Rh}_{2}\left(\mu-\mathrm{S}_{2} \mathrm{Cptn}\right)(\operatorname{cod})_{2}\right](1)\left(\mathrm{CptnS}_{2}{ }^{2-}\right.$ $=1,1$-cyclopentanedithiolato $), \quad\left[\mathrm{Rh}_{2}\left(\mu-\mathrm{S}_{2} \mathrm{Chxn}\right)(\mathrm{cod})_{2}\right] \quad(2) \quad\left(\mathrm{ChxnS}_{2}{ }^{2-}=1,1-\right.$ cyclohexanedithiolato), $\quad\left[\mathrm{Rh}_{2}\left(\mu-\mathrm{S}_{2} \mathrm{CBn}_{2}\right)(\mathrm{cod})_{2}\right] \quad$ (3) $\quad\left(\mathrm{Bn}_{2} \mathrm{CS}_{2}{ }^{2-}=1,3-\right.$ diphenyl-2,2dithiolatopropane) and $\left[\mathrm{Rh}_{2}\left(\mu-\mathrm{S}_{2} \mathrm{C}^{i} \mathrm{Pr}_{2}\right)(\mathrm{cod})_{2}\right]$ (4) $\left({ }^{i} \mathrm{Pr}_{2} \mathrm{CS}_{2}{ }^{2-}=\right.$ 2,4-dimethyl-2,2dithiolatopentane) dissolved in toluene in the presence of monodentate phosphine or phosphite P-donor ligands under carbon monoxide/hydrogen (1:1) atmosphere are efficient catalysts for the hydroformylation of oct-1-ene under mild conditions (6.8 atm of $\mathrm{CO} / \mathrm{H}_{2}$ and $80{ }^{\circ} \mathrm{C}$ ). The influence of the gem-dithiolato ligand, the P-donor cocatalyst and the P/Rh ratio on the catalytic activity and selectivity has been explored. Aldehyde selectivities higher than $95 \%$ and turnover frequencies up to $245 \mathrm{~h}^{-1}$ have been obtained using $\mathrm{P}(\mathrm{OMe})_{3}$ as modifying ligand. Similar activity figures have been obtained using $\mathrm{P}(\mathrm{OPh})_{3}$ although the selectivities are lower. Regioselectivities toward linear aldehyde are in the range 75 to $85 \%$. The performance of the catalytic systems $\left[\mathrm{Rh}_{2}\left(\mu-\mathrm{S}_{2} \mathrm{CR}_{2}\right)(\mathrm{CO})_{2}\left(\mathrm{PPh}_{3}\right)_{2}\right] / \mathrm{PPh}_{3}$ has been found to be comparable to the systems $\left[\mathrm{Rh}_{2}\left(\mu-\mathrm{S}_{2} \mathrm{CR}_{2}\right)(\operatorname{cod})_{2}\right]$ at the same $\mathrm{P} / \mathrm{Rh}$ ratio. The system $\left[\mathrm{Rh}_{2}\left(\mu-\mathrm{S}_{2} \mathrm{CBn}_{2}\right)(\operatorname{cod})_{2}\right]$ $(3) / \mathrm{P}(\mathrm{OPh})_{3}$ has been tested in the hydroformylation-isomerization of trans-oct-2-ene. Under optimized conditions up to $54 \%$ of regioselectivity in 1-nonanal was obtained. Spectroscopic studies under pressure (HPNMR and HPIR) evidenced the formation of hydrido mononuclear species under catalytic conditions that are most probably responsible for the observed catalytic activity.

Keywords: Homogeneous catalysis, Hydroformylation, Dinuclear complexes, Gemdithiolato ligands, Rhodium, HPNMR, HPIR. 


\section{Introduction}

The hydroformylation of alkenes is one of the most important transition metal homogeneously catalyzed reactions [1]. Mononuclear rhodium complexes are the most efficient catalysts for this reaction and, consequently, a great deal of work has been devoted to the improvement of rates and selectivities by ligand design [2-4]. However, bimetallic catalysis has attracted considerable interest in recent years [5-6]. The potential of both homo- and heterobimetallic compounds as hydroformylation catalyst concerns the expected cooperation between the metal atoms that should result in more active and selective catalysts [7-8]. However, fragmentation has been a major problem in polymetallic catalysts and, although a number of bimetallic hydroformylation catalysts have been reported [9], the evidences for a bimetallic mechanism are scarce [10]. The design of binucleating ligands is of major importance in the control of the structure of the complexes, as they should produce flexible structures allowing the accommodation of the metal centers in close proximity but preventing it from fragmentation [11].

Dinuclear $d^{8}$ rhodium complexes doubly bridged with thiolato ligands, $\left[R h_{2}(\mu-\right.$ $S R)_{2} L_{4}$, were discovered to be effective catalysts for the hydroformylation of olefins under mild conditions in the early eighties [12]. Subsequent advances in rhodium thiolate chemistry were focused on the utilization of modified thiolato and dithiolato ligands searching for the influence of a more rigid structure on the catalytic activity [13]. However, the dinuclear structure of the active catalytic species has been questioned as kinetic studies suggested the involvement of mononuclear species [14]. In fact, high-pressure spectroscopic techniques (HPNMR and HPIR) have shown that some thiolato- and dithiolato dinuclear rhodium complexes evolve to mononuclear rhodium hydride complexes under hydroformylation conditions [15]. 
We have recently reported the synthesis of dinuclear rhodium complexes supported by gem-dithiolato ligands [16-17]. The bridging and chelating coordination mode of these ligands $\left(1: 2 k^{2} S, 1: 2 k^{2} S^{\prime}\right)$ and the presence of a single bridgehead carbon atom between both sulphur atoms, introduce important geometrical constraints that result in a more rigid and compact $\left[R h\left(\mu-S_{2} C R_{2}\right) R h\right]$ core. Interestingly, preliminary studies have shown that the gem-dithiolato complex $\left[R h_{2}(\mu-\right.$ $\left.\left.\mathrm{S}_{2} \mathrm{Chxn}\right)(\mathrm{cod})_{2}\right]\left(\mathrm{ChxnS}_{2}{ }^{2-}=1,1\right.$-cyclohexanedithiolato $)$ is an active catalyst precursor for the hydroformylation of oct-1-ene under mild conditions [16]. In addition to the singular structural features of the compact $\mathrm{Rh}_{2} \mathrm{~S}_{2}$ core imparted by the gem-dithiolato bridging ligand, it is important to note that the $\mathrm{R}$ groups on the $\mathrm{sp}^{3}$ bridgehead carbon atom are directly oriented toward the rhodium atoms, and not toward the center of the dinuclear unit as in the bis-thiolato or dithiolato dinuclear counterparts. This fact suggests that the structure of the gem-dithiolato ligand could have a determining steric influence in the hydroformylation reaction.

We report herein on the catalytic activity for the hydroformylation of oct-1-ene of a series of gem-dithiolato dinuclear complexes $\left[R h_{2}\left(\mu-S_{2} C R_{1} R_{2}\right)(\operatorname{cod})_{2}\right]\left(R^{1}, R^{2}=-\right.$ $\left.\left(\mathrm{CH}_{2}\right)_{4^{-}},-\left(\mathrm{CH}_{2}\right)_{5^{-}} ; \mathrm{R}^{1}=\mathrm{R}^{2}=\mathrm{Bn},{ }^{i} \mathrm{Pr}\right)$ in the presence of different monodentate P-donor ligands. The aim of this study is to determine the influence of the nature of the gemdithiolato and auxiliary ligands both on the selectivity, regioselectivity and catalytic activity. In addition, the robustness of the dinuclear framework under hydroformylation conditions has been investigated by high-pressure spectroscopic techniques (HPNMR and HPIR). 


\section{Experimental}

\subsection{Materials and instrumentation}

All manipulations were performed under a dry argon atmosphere using Schlenk-tube techniques. Solvents were dried by standard methods and distilled under argon immediately prior to use. The dinuclear gem-dithiolato rhodium(I) complexes $\left[\mathrm{Rh}_{2}\left(\mu-\mathrm{S}_{2} \mathrm{CR}_{2}\right)(\mathrm{cod})_{2}\right]\left(\mathbf{1}\right.$ - 4) and $\left[\mathrm{Rh}_{2}\left(\mu-\mathrm{S}_{2} \mathrm{CR}_{2}\right)(\mathrm{CO})_{2}\left(\mathrm{PPh}_{3}\right)_{2}\right](\mathbf{5}$ - 8) were prepared by reaction of the corresponding gem-dithiol compounds and standard rhodium starting materials, typically $[\mathrm{Rh}(\mu-\mathrm{OH})(\operatorname{cod})]_{2}$ and $\left[\mathrm{Rh}(\mathrm{acac})(\mathrm{CO})\left(\mathrm{PPh}_{3}\right)\right]$, following the procedure recently reported. The molecular structure of compounds $\mathbf{1}$, 3, 4 and 6 has been determined by X-ray diffraction methods [16-17]. Oct-1-ene was purchased from Aldrich and was distilled prior to use.

Hydroformylation experiments were carried out in a stainless steel magnetically stirred autoclave $(100 \mathrm{~mL})$ equipped with a thermocouple and an external heating mantle. The syngas $\left(\mathrm{CO} / \mathrm{H}_{2}=1\right)$ was supplied at constant pressure from a ballast. The drop in pressure in the ballast was monitored using a pressure transmitter. Gas samples analyses from the catalytic runs were performed on a Hewlett-Packard 5890 Series II programmable gas chromatograph fitted with a flame ionization detector and Ultra 1-HP crosslinked Methyl Silicon Gum $(25 \mathrm{~m}$ x $0.32 \mathrm{~mm}$ x $0.17 u \mathrm{~m}$ film thickness) column. The column temperature was programmed from 35 to $220{ }^{\circ} \mathrm{C}\left(15{ }^{\circ} \mathrm{C} / \mathrm{min}\right)$ at a flow rate of $25 \mathrm{~mL} / \mathrm{min}$ using ultra pure nitrogen $\left(\mathrm{N}_{2}\right)$ as carrier gas. Also the organic products were separated by column chromatography and analyzed by ${ }^{1} \mathrm{H}$, and ${ }^{13} \mathrm{C}\left\{{ }^{1} \mathrm{H}\right\}$ NMR on a Varian Gemini 300 spectrometer operating at 300.08 and $75.46 \mathrm{MHz}$, respectively. Chemical shifts were referenced to $\mathrm{Me}_{4} \mathrm{Si}$ using the signal of the deuterated solvent. 


\subsection{Standard hydroformylation experiment}

In a typical run, a solution containing the dinuclear rhodium catalyst precursor (0.017 $\mathrm{mmol})$, the phosphite or phosphine ligand $(0.34-13.6 \mathrm{mmol})$, oct-1-ene $(10.2$ $\mathrm{mmol})$, and toluene $(15.4 \mathrm{~mL})$ was transferred under argon from a Schlenk tube to the autoclave by using a stainless steel cannula. The autoclave was purged with syngas three times at $8.2 \mathrm{~atm}$ and then pressurized at $3.4 \mathrm{~atm}$ and heated to $80^{\circ} \mathrm{C}$. When the thermal equilibrium was reached, the pressure was adjusted to $6.8 \mathrm{~atm}$ and the mixture stirred at constant speed. These pressure and temperature values were chosen as an average from previously reported systems [18]. After the reaction time, the autoclave was cooled to room temperature and depressurized. The reaction mixture was analyzed by gas chromatography. The products were quantified by the internal standard method using anisole.

\subsection{HPNMR and HPIR spectroscopic measurements}

High-pressure NMR experiments (HPNMR) were carried out in a $10 \mathrm{~mm}$ diameter sapphire tube with a titanium cap equipped with a Teflon/polycarbonate protection [19] and recorded on a Varian Gemini 2000 spectrometer operating at 300.08 MHz. In a typical experiment, the NMR tube was filled under $\mathrm{N}_{2}$ with a solution of $\left[\mathrm{Rh}_{2}\left(\mu-\mathrm{S}_{2} \mathrm{CBn}_{2}\right)(\mathrm{cod})_{2}\right](3)(0.05 \mathrm{mmol})$, the $\mathrm{P}$-donor ligand $(0.40 \mathrm{mmol})$ and toluene- $\mathrm{d}_{8}(2 \mathrm{ml})$. The tube was pressurised to $6.8 \mathrm{~atm} \mathrm{CO} / \mathrm{H}_{2}(1 / 1)$, left for $1 \mathrm{~h}$ under agitation at $80^{\circ} \mathrm{C}$, and the NMR spectra were recorded.

High-pressure IR experiments were performed in an in situ infrared autoclave [20] and recorded in a FT-IR Bruker Equinox-55 spectrometer. In a typical experiment, the HPIR cell was filled under $\mathrm{N}_{2}$ with a solution of $\left[\mathrm{Rh}_{2}\left(\mu-\mathrm{S}_{2} \mathrm{CBn} \mathrm{n}_{2}\right)(\operatorname{cod})_{2}\right]$ (3) $(0.015 \mathrm{mmol})$, the P-donor ligand $(0.120 \mathrm{mmol})$ and methyltetrahydrofuran $(15$ 
$\mathrm{ml})$. The cell was pressurised to $6.8 \mathrm{~atm} \mathrm{CO} / \mathrm{H}_{2}(1 / 1)$, stirred for $1 \mathrm{~h}$ at $80^{\circ} \mathrm{C}$, and the IR spectra were recorded.

\section{Results}

\subsection{General aspects}

The dinuclear complexes $\left[\operatorname{Rh}_{2}\left(\mu-S_{2} \operatorname{Cptn}\right)(\operatorname{cod})_{2}\right](1),\left[\operatorname{Rh}_{2}\left(\mu-S_{2} \operatorname{Chxn}\right)(\operatorname{cod})_{2}\right](2)$, $\left[\mathrm{Rh}_{2}\left(\mu-\mathrm{S}_{2} \mathrm{CBn}_{2}\right)(\operatorname{cod})_{2}\right]$ (3) and $\left[\mathrm{Rh}_{2}\left(\mu-\mathrm{S}_{2} \mathrm{C}^{i} \mathrm{Pr}_{2}\right)(\operatorname{cod})_{2}\right](4)$ (Figure 1) dissolved in toluene in the presence of $\mathrm{P}$-donor ligands: $\mathrm{P}(\mathrm{OPh})_{3}$ (triphenyl phosphite), $\mathrm{P}(\mathrm{OMe})_{3}$ (trimethyl phosphite), $\mathrm{PPh}_{3}$ (triphenylphosphine), $\mathrm{PMe}_{3}$ (trimethylphosphine), $\mathrm{P}^{i} \mathrm{Pr}_{3}$ (triisopropylphosphine) or $\mathrm{PCy}_{3}$ (tricyclohexylphosphine); under the following standard operation conditions: $6.8 \mathrm{~atm}$ of $\mathrm{CO} / \mathrm{H}_{2}(1: 1), 80^{\circ} \mathrm{C},\left[R \mathrm{Rh}_{2}\right]=1.0 \mathrm{mM}, \mathrm{P} / \mathrm{Rh}=$

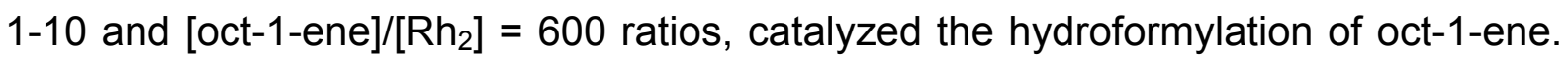
${ }^{1} \mathrm{H}$ NMR and GC analyses of the liquid phase runs allowed the identification of 1nonanal and 2-methyl-octanal as major products (Scheme 1), variable amounts of internal oct-n-enes (mainly cis and trans-oct-2-ene) and traces of octane. Complexes $\left[\mathrm{Rh}_{2}\left(\mu-\mathrm{S}_{2} \mathrm{CR}_{2}\right)(\operatorname{cod})_{2}\right](\mathbf{1}-\mathbf{4})\left(\mathrm{CR}_{2}=\mathrm{Cptn}, \mathrm{Chxn}, \mathrm{CBn}_{2}\right.$ or $\left.\mathrm{C}^{i} \mathrm{Pr}_{2}\right)$ under syn-gas without added P-donor ligand gave the tetracarbonyl $\left[\mathrm{Rh}_{2}\left(\mu-\mathrm{S}_{2} \mathrm{CR}_{2}\right)(\mathrm{CO})_{4}\right]$ complexes [17] which are inactive for the hydroformylation of oct-1-ene under the reaction conditions described above. Further, control experiments showed that the hydroformylation and isomerization of oct-1-ene under $\mathrm{CO} / \mathrm{H}_{2}$ was not observed when a mixture of toluene and oct-1-ene was tested under similar experimental conditions in the absence of any of these rhodium catalysts. The next sections show detailed results of this investigation.

$<$ Figure 1 and Scheme 1, about here> 
3.2. Hydroformylation of oct-1-ene by the system $\left[R h_{2}\left(\mu-S_{2} C R_{2}\right)(\operatorname{cod})_{2}\right] / P(O P h)_{3}$

Table 1 summarizes the results of the catalytic hydroformylation of oct-1-ene by the complexes $\left[\mathrm{Rh}_{2}\left(\mu-\mathrm{S}_{2} \mathrm{CR}_{2}\right)(\mathrm{cod})_{2}\right](\mathbf{1}-\mathbf{4})$ in toluene. Under the same reaction conditions, $\mathrm{P}\left(\mathrm{CO} / \mathrm{H}_{2}\right)=6.8 \mathrm{~atm}$ at $80{ }^{\circ} \mathrm{C}$ for $2 \mathrm{~h},\left[\mathrm{Rh}_{2}\right]=1.0 \mathrm{mM}$ and [oct-1-ene] $/\left[\mathrm{Rh}_{2}\right]$ $=600$, the observed TOF(Ald) depends both on the nature of the gem-dithiolato ligand and the $\mathrm{P}(\mathrm{OPh})_{3} / \mathrm{Rh}$ ratio. For the same $\mathrm{P}(\mathrm{OPh})_{3} / \mathrm{Rh}=4$ ratio, the TOF(Ald) follows the order $230(3)>222(2)>66(1)>41 h^{-1}$ (4) (runs 1, 5, 9 and 12). However, the sequence is $228(4)>217(2)>213(3)>122 \mathrm{~h}^{-1}(\mathbf{1})$ at $\mathrm{P}(\mathrm{OPh})_{3} / \mathrm{Rh}=6$ (runs 2, 6, 8 and 13) as a consequence of the unexpected increase in the activity for precursor 4. This behavior reveals the importance of the $\mathrm{P}(\mathrm{OPh})_{3} / \mathrm{Rh}$ ratio in the promotion of the hydroformylation. In general, at low $\mathrm{P}(\mathrm{OPh})_{3} / \mathrm{Rh}$ ratios the catalytic activities are low and reach a maximum value at $\mathrm{P}(\mathrm{OPh})_{3} / \mathrm{Rh}=4$ (complexes 2 and 3) or 6 (complex 4). Interestingly, comparable TOF(Ald) numbers were attained with precursor 1 at higher $\mathrm{P}(\mathrm{OPh})_{3} / \mathrm{Rh}$ ratios (Figure 2).

$<$ Table 1 , about here $>$

The selectivity towards aldehyde (typically $>70 \%$ ) is moderate due to the extensive oct-1-ene isomerization that competes with the hydroformylation reaction. In general, the aldehyde selectivity improves with the increase of the $\mathrm{P}(\mathrm{OPh})_{3} / \mathrm{Rh}$ ratio as a consequence of a slight inhibition of the isomerization reaction. This tendency is shown for precursors $\mathbf{3}$ and $\mathbf{4}$. Noteworthy, an excellent selectivity in aldehyde was observed for the catalytic system $1 / \mathrm{P}(\mathrm{OPh})_{3}$ at $\mathrm{P}(\mathrm{OPh})_{3} / \mathrm{Rh}=6(96.9$ $\%$, run 2). However, the aldehyde selectivity for complex 2 decreases as the $\mathrm{P}(\mathrm{OPh})_{3} / \mathrm{Rh}$ ratio increases (Figure 3).

$<$ Figures 2 and 3 , about here $>$ 
The temperature strongly influences the extension of the isomerization process. Thus, an upsurge in the isomerization activity from $20.0 \%$ (run 9) to $57.8 \%$ was observed for complex 3 when the temperature was increased from 80 to $100{ }^{\circ} \mathrm{C}$ (run 10 , Table 1). Interestingly, a better activity and selectivity to aldehyde at $100^{\circ} \mathrm{C}$ can be reached by increasing the $\mathrm{P}(\mathrm{OPh})_{3} / \mathrm{Rh}$ ratio from 4 to 10 (run 11). However, the increment of the temperature has a negative effect on the regioselectivity ( $\%$ of linear aldehyde). In addition, 2-ethyl-heptanal and 2-propyl-hexanal, coming from the hydroformylation of internal olefins formed under catalytic conditions, were also detected together with 1-nonanal and 2-methyl-octanal (runs 10 and 11, Table 1).

The observed regioselectivities for these systems are in the range of 83 to $86 \%$. In general, the regioselectivity improves with the increase of the $\mathrm{P}(\mathrm{OPh})_{3} / \mathrm{Rh}$ ratio and reaches constant values for complexes 1, $\mathbf{3}$ and $\mathbf{4}$. However, the catalytic system involving complex 2 showed the maximum regioselectivity at $\mathrm{P}(\mathrm{OPh})_{3} / \mathrm{Rh}=2$ (89\%, run 4, Table 1) although, unfortunately, the catalytic activity was low under these conditions $\left(45 \mathrm{~h}^{-1}\right)$.

\subsection{Hydroformylation of oct-1-ene by the system $\left[R h_{2}\left(\mu-S_{2} C R_{2}\right)(\operatorname{cod})_{2}\right] / P(O M e)_{3}$}

The dinuclear complexes $\left[R h_{2}\left(\mu-S_{2} C R_{2}\right)(\operatorname{cod})_{2}\right](1-4)$ also catalyzed the hydroformylation of oct-1-ene using $\mathrm{P}(\mathrm{OMe})_{3}$ as co-catalyst. The influence of the $\mathrm{P}(\mathrm{OMe})_{3} / \mathrm{Rh}$ ratio both on the activity and selectivity is shown in Table 2 .

$<$ Table 2, about here $>$

The catalytic activities in the hydroformylation of oct-1-ene at $\mathrm{P}(\mathrm{OMe})_{3} / \mathrm{Rh}=4$ ratio under the same reaction conditions $\left(\mathrm{P}\left(\mathrm{CO} / \mathrm{H}_{2}\right)=6.8 \mathrm{~atm}\right.$ at $80{ }^{\circ} \mathrm{C}$ for $\left.2 \mathrm{~h}\right)$ follow the order: $245(4)>219(3)>198(2)>157 h^{-1}$ (1) (runs 16, 19, 22 and 25, Table 2) being complex $\left[\mathrm{Rh}_{2}\left(\mu-\mathrm{S}_{2} \mathrm{C}^{i} \mathrm{Pr}_{2}\right)(\mathrm{cod})_{2}\right]$ (4) the most active. Interestingly, higher 
conversions can be reached with the rest of the precursors at longer reaction times with the same selectivity indicating that isomerization competes with hydroformylation at the same rate.

The observed values of TOF(Ald) strongly depend on the $\mathrm{P}(\mathrm{OMe})_{3} / \mathrm{Rh}$ ratio (Table 2). In general, the catalytic activity improves with the increase of the $\mathrm{P}(\mathrm{OMe})_{3} / \mathrm{Rh}$ ratio under the same reaction conditions. However, the TOF(Ald) value reach a maximum at $\mathrm{P}(\mathrm{OMe})_{3} / \mathrm{Rh}=4$ and decrease at higher $\mathrm{P}(\mathrm{OMe})_{3} / \mathrm{Rh}$ ratios (Figure 4). These results suggest existence of a critical concentration of $\mathrm{P}(\mathrm{OMe})_{3}$ in order to generate a sufficient concentration of active species although higher concentrations probably result in the formation of coordinatively saturated rhodium species which are less active.

\section{$<$ Figures 4 about here>}

The aldehyde selectivity for these catalytic systems is high (typically > $95 \%$ ). The amount of octane is $<1 \%$ and the formation of internal olefins is $<5 \%$. In general, the aldehyde selectivity was slightly improved when the $\mathrm{P}(\mathrm{OMe})_{3} / \mathrm{Rh}$ ratio was increased from 2 to 4 , although further increments of the $\mathrm{P}(\mathrm{OMe})_{3} / \mathrm{Rh}$ ratio do not inhibit the isomerization reaction and the aldehyde selectivity remains almost constant (Table 2). On the other hand, the extension of the isomerization process depends on the temperature but it is less affected by the variation of the $P\left(C O / H_{2}\right)$.

Finally, it is noticeable that the increase of the $\mathrm{P}(\mathrm{OMe})_{3} / \mathrm{Rh}$ ratio results in a steady increase of the regioselectivity. The observed regioselectivity are about $80 \%$ at the optimal $\mathrm{P}(\mathrm{OMe})_{3} / \mathrm{Rh}=4$ ratio for the four catalyst precursors. 
3.4. Hydroformylation of oct-1-ene by the system $\left[R h_{2}\left(\mu-S_{2} C R_{2}\right)(\operatorname{cod})_{2}\right] / P P h_{3}$

The experimental results on the hydroformylation of oct-1-ene by the systems $\left[\mathrm{Rh}_{2}\left(\mu-\mathrm{S}_{2} \mathrm{CR}_{2}\right)(\mathrm{cod})_{2}\right] / \mathrm{PPh}_{3}$ are summarized in Table 3. In general, these systems are less active than the systems based on phosphite ligands. The catalytic activities in the hydroformylation of oct-1-ene at $\mathrm{PPh}_{3} / \mathrm{Rh}=4$ ratio under the same reaction conditions $\left(\mathrm{P}\left(\mathrm{CO} / \mathrm{H}_{2}\right)=6.8\right.$ atm at $80{ }^{\circ} \mathrm{C}$ for $\left.2 \mathrm{~h}\right)$ follows the order: $219(4)>126(3)>$ $107 \mathrm{~h}^{-1}$ (2) (runs 30, 34 and 39, Table 3). The catalytic activity for the complex 1 under similar conditions is too low.

$<$ Table 3, about here $>$

The behavior of this system is similar to the observed for the previously described systems based on phosphite ligands, in fact the maximum TOF(Ald) was attained at a $\mathrm{PPh}_{3} / \mathrm{Rh}=4$ ratio. In addition, the aldehyde selectivity increases gradually with the $\mathrm{PPh}_{3} / \mathrm{Rh}$ ratio, while regioselectivity increases very slowly, reaching values up to $76 \%$ for the linear aldehyde.

The evolution of the TOF(Ald) and conversion with the reaction time has been studied for precursors $\left[R h_{2}\left(\mu-S_{2} C h x n\right)(\operatorname{cod})_{2}\right](2)$ and $\left[R_{2}\left(\mu-S_{2} C B n h_{2}\right)(\operatorname{cod})_{2}\right]$ (Figure 5). In the case of complex 3 at $\mathrm{PPh}_{3} / \mathrm{Rh}=4$ ratio (runs $34-36$, Table 3 ), it can be observed a gradually increase of the conversion values from 46.4 to $96.1 \%$ when the reaction time increase from 2 to $6 \mathrm{~h}$ (Figure 5b). As expected, the TOF(Ald) values decrease from 126 to $89 \mathrm{~h}^{-1}$ with the reaction time but the aldehyde selectivity $(91 \%)$ and the regioselectivity $(76 \%)$ are practically constant along the hydroformylation reaction. In addition, an increase of the $\mathrm{PPh}_{3} / \mathrm{Rh}$ molar ratio from 4 to 6 gave similar TOF(Ald), conversion or aldehyde selectivity numbers (reaction time 
$6 \mathrm{~h}$ ), although the regioselectivity was increased from $75 \%$ to $80 \%$ (runs 36 and 37 , Table 3).

The behavior of the catalyst precursor $\left[\mathrm{Rh}_{2}\left(\mu-\mathrm{S}_{2} \mathrm{Chxn}\right)(\mathrm{cod})_{2}\right](2)$ in using $\mathrm{PPh}_{3}$ as co-catalyst is unusual. The evolution of the observed TOF(Ald) and conversion values at $\mathrm{PPh}_{3} / \mathrm{Rh}=4$ follows an unexpected trend all the way through the time (runs $30-33$, Table 3). The reaction reaches about a $38.4 \%$ of conversion at the first two hours. However, there is not a significant increment in the conversion in the following four hours: $40.8 \%$ and $41.8 \%$ at reaction times of 4 and $6 \mathrm{~h}$, respectively. From this point, there is a steady progress of the reaction, which reaches a conversion up to 65 $\%$ in $12 \mathrm{~h}$ (Figure 5a). Accordingly, the observed trend in conversion, which is reflected in the sharp decrease of the catalytic activity, TOF(Ald), suggest the presence of different active catalytic species through the reaction time.

<Figures 5 about here>

The catalyst precursor $\left[\operatorname{Rh}_{2}\left(\mu-S_{2} \operatorname{Cptn}\right)(\operatorname{cod})_{2}\right](1)$ behaves similarly to precursor 2. The catalytic activity $\left(15 \mathrm{~h}^{-1}\right)$ and the conversion $(16.7 \%)$ are low in the first $6 \mathrm{~h}$ at $\mathrm{PPh}_{3} / \mathrm{Rh}=4$ (run 27, Table 3). However, there is a significant increment both on the catalytic activity $\left(44 \mathrm{~h}^{-1}\right)$ and the conversion (93.8\%) (run 28, Table 3) at longer reaction times $(12 \mathrm{~h})$. In addition, the regioselectivity increases from $68 \%$ at $6 \mathrm{~h}$ to $75 \%$ at 12 h. An increment of the $\mathrm{PPh}_{3} / \mathrm{Rh}$ ratio from 4 to 6 decreases both the catalytic activity, from 44 to $32 \mathrm{~h}^{-1}$, and the conversion, from 93.8 to $68.5 \%$. However, the regioselectivity was increased up to $81 \%$ (runs 28 and 29, Table 3). 
3.5. Hydroformylation of oct-1-ene by the systems $\left[R h_{2}\left(\mu-S_{2} C R_{2}\right)(\operatorname{cod})_{2}\right] / P C y_{3}, P^{i} P r_{3}$, and $\mathrm{PMe}_{3}$

A comparative study of the catalytic activity of complexes $\left[\mathrm{Rh}_{2}\left(\mu-\mathrm{S}_{2} C \mathrm{R}_{2}\right)(\mathrm{cod})_{2}\right]$ (1 - 4) with diverse phosphine ligands has been carried out. Table 4 summarizes the results observed in the hydroformylation of oct-1-ene by $\left[R h_{2}\left(\mu-S_{2} \operatorname{Chxn}\right)(\operatorname{cod})_{2}\right](2)$ using different $\mathrm{PR}_{3}$ ligands as co-catalysts $\left(\mathrm{PR}_{3}=\mathrm{PCy}, \mathrm{P}^{i} \mathrm{Pr}_{3}\right.$ or $\left.\mathrm{PMe}_{3}\right)$.

It can be observed that the TOF(Ald) values for the systems $2 / \mathrm{PR}_{3}$ follows the order $\mathrm{P}^{i} \mathrm{Pr}_{3}(44)>\mathrm{PPh}_{3}(38)>\mathrm{PMe}_{3}(27)>\mathrm{PCy}_{3}\left(20 \mathrm{~h}^{-1}\right)$ under the same conditions $\left(\mathrm{PR}_{3} / \mathrm{Rh}=4, \mathrm{P}\left(\mathrm{CO} / \mathrm{H}_{2}\right)=6.8\right.$ atm at $80^{\circ} \mathrm{C}$ for $6 \mathrm{~h}$ ) (run 32, Table 3 and runs $41-43$, Table 4). Interestingly, the systems $2 / \mathrm{PCy}_{3}, 2 / \mathrm{P}^{i} \mathrm{Pr}_{3}$ and $2 / \mathrm{PMe}_{3}$ are highly selective towards the aldehyde formation (100\%). The regioselectivity follows the order $\mathrm{PPh}_{3}$ (75) $>\mathrm{PMe}_{3}(72)>\mathrm{PCy}_{3}(57)>\mathrm{P}^{i} \mathrm{Pr}_{3}(51 \%)$ (Figure 6).

$<$ Table 4 and Figure 6, about here>

Table 5 summarizes the experimental data for the hydroformylation of oct-1ene catalyzed by the systems $\left[R h_{2}\left(\mu-S_{2} C R_{2}\right)(\operatorname{cod})_{2}\right] / P C y_{3}$ under the same reaction conditions for a longer reaction time (12 hours) as a way to obtain higher conversions. In fact, this goal was achieved for the catalytic systems $1 / \mathrm{PC}_{3}$ and 4/PCy $y_{3}$ which shown conversions up to $90 \%$ (runs 44 and 47 ), whereas that $2 / \mathrm{PC} y_{3}$ and $3 / \mathrm{PCy}_{3}$ showed moderate conversions, 43.9 and $71.2 \%$, respectively (runs 45 and 46). The TOF(Ald) values for the systems $\left[\mathrm{Rh}_{2}\left(\mu-\mathrm{S}_{2} \mathrm{CR}_{2}\right)(\operatorname{cod})_{2}\right] / \mathrm{PCy}_{3}$ follows the order $4(140)>1(134)>3(103)>2\left(61 h^{-1}\right)($ runs $44-47$, Table 5) under the same catalytic conditions: $\mathrm{P} / \mathrm{Rh}=4, \mathrm{P}\left(\mathrm{CO} / \mathrm{H}_{2}\right)=6.8 \mathrm{~atm}$ at $80^{\circ} \mathrm{C}$ for $12 \mathrm{~h}$.

$<$ Table 5 about here> 
In general, the four systems are less active than the related systems based on $\mathrm{PPh}_{3}$. However, the selectivities to aldehyde are comparable (>90\%) although the observed regioselectivity are in significantly lower ( $\approx 55 \%)$.

The above described results show that catalytic activity of the systems $\left[\mathrm{Rh}_{2}(\mu-\right.$ $\left.\left.\mathrm{S}_{2} \mathrm{CR}_{2}\right)(\mathrm{cod})_{2}\right](1-4) / \mathrm{PR}_{3}$ depend on the electronic properties of the phosphine cocatalysts. The $\mathrm{PCy}_{3}, \mathrm{PiPr}_{3}$ and $\mathrm{PMe}_{3}$ ligands are more basic than $\mathrm{PPh}_{3}$, which in general is the most active co-catalyst. However, there is not a clear correlation between the regioselectivity and the steric influence of the ligands as the cone angle decrease as follows: $\mathrm{PCy}_{3}(170)>\mathrm{PiPr}_{3}(160)>\mathrm{PPh}_{3}(145)>\mathrm{PMe}_{3}\left(118^{\circ}\right)$ [21].

\subsection{Hydroformylation of oct-1-ene by the system $\left[R h_{2}\left(\mu-S_{2} C R_{2}\right)(C O)_{2}\left(P P h_{3}\right)_{2}\right] / P P h_{3}$}

It is predicable that under the hydroformylation conditions (moderate temperature and $\mathrm{CO} / \mathrm{H}_{2}$ pressure, and an excess of $\mathrm{PR}_{3}$ ), the olefin precursors $\left[R h_{2}\left(\mu-S_{2} C R_{2}\right)(\operatorname{cod})_{2}\right]$ should be converted into the mixed ligand complexes $\left[R h_{2}(\mu-\right.$ $\left.\left.\mathrm{S}_{2} \mathrm{CR}_{2}\right)(\mathrm{CO})_{2}\left(\mathrm{PR}_{3}\right)_{2}\right]$. For that reason, we have studied the catalytic activity of the systems $\left[\mathrm{Rh}_{2}\left(\mu-\mathrm{S}_{2} \mathrm{CR}_{2}\right)(\mathrm{CO})_{2}\left(\mathrm{PPh}_{3}\right)_{2} / \mathrm{PPh}_{3}\right.$ in order to compare with the systems $\left[\mathrm{Rh}_{2}\left(\mu-\mathrm{S}_{2} \mathrm{CR}_{2}\right)(\mathrm{cod})_{2}\right] / \mathrm{PPh}_{3}$ previously described.

Table 6 summarizes the experimental data for the hydroformylation of oct-1ene catalyzed by complexes $\left[\mathrm{Rh}_{2}\left(\mu-\mathrm{S}_{2} \mathrm{Cptn}\right)(\mathrm{CO})_{2}\left(\mathrm{PPh}_{3}\right)_{2}\right] \quad(5), \quad\left[\mathrm{Rh}_{2}(\mu-\right.$ $\left.\left.\mathrm{S}_{2} \mathrm{Chxn}\right)(\mathrm{CO})_{2}\left(\mathrm{PPh}_{3}\right)_{2}\right] \quad(6), \quad\left[\mathrm{Rh}_{2}\left(\mu-\mathrm{S}_{2} \mathrm{CBn}_{2}\right)(\mathrm{CO})_{2}\left(\mathrm{PPh}_{3}\right)_{2}\right] \quad(7) \quad$ and $\quad\left[\mathrm{Rh}_{2}(\mu-\right.$ $\left.\left.\mathrm{S}_{2} \mathrm{C}^{\mathrm{i}} \mathrm{Pr}_{2}\right)(\mathrm{CO})_{2}\left(\mathrm{PPh}_{3}\right)_{2}\right](8)$ in the presence of $\mathrm{PPh}_{3}$.

The TOF(Ald) values for these systems follows the order $8(131)>7(128)>6$ (24) > $5\left(21 \mathrm{~h}^{-1}\right)$ (runs 48, 50, 52 and 53, Table 6) under the same conditions: $\mathrm{PPh}_{3} / \mathrm{Rh}=4, \mathrm{P}\left(\mathrm{CO} / \mathrm{H}_{2}\right)=6.8$ atm at $80{ }^{\circ} \mathrm{C}$ for $4 \mathrm{~h}$. Interestingly, only the catalytic 
activity and the conversion are affected by the nature of the gem-dithiolato ligand, as the observed aldehyde selectivity and regioselectivity values are very similar.

\section{$<$ Table 6 about here $>$}

It has been found that catalytic systems based on diolefin dinuclear complexes having azolate bridging ligands in the presence of $\mathrm{PR}_{3}$, are far more active than the preformed mixed carbonyl-phosphine species under the same experimental conditions [22]. In the same way, dinuclear complexes with zwitterionic aminothiolato ligands represent an extreme example of this behavior as the diolefin complex is active for hydroformylation of 1-hexene but the trans- mixed carbonylphosphine complex is inactive [23]. The above described results indicate that there is not an additional benefit on the catalytic activity by using preformed mixed carbonylphosphine dinuclear gem-dithiolato complexes over the diolefin complexes as comparable chemio-, regioselectivities and activities were obtained when using the same P/Rh ratio.

3.7. Hydroformylation of trans-oct-2-ene by the system $\left[R h_{2}\left(\mu-S_{2} C B n_{2}\right)(c o d)_{2}\right]$ (3)/P(OPh) 3

The transformation of internal olefins to linear aldehydes is of considerable industrial interest since internal olefins are cheaper and more readily available feedstock than terminal olefins $[24,25]$. Recently, several highly selective and active isomerization-hydroformylation catalysts that contain phosphonite [26], diphosphine [27] or diphosphite [28] ligands have been developed. On the light of the significant isomerization activity exhibited by the systems $\left[\mathrm{Rh}_{2}\left(\mu-\mathrm{S}_{2} \mathrm{CR}_{2}\right)(\operatorname{cod})_{2}\right] / \mathrm{P}(\mathrm{OPh})_{3}$, we have studied the catalytic activity of the system $\left[\mathrm{Rh}_{2}\left(\mu-\mathrm{S}_{2} \mathrm{CBn}_{2}\right)(\mathrm{cod})_{2}\right](3) / \mathrm{P}(\mathrm{OPh})_{3}$ for the hydroformylation of trans-oct-2-ene. 
The hydroformylation of trans-oct-2-ene has been carried out in toluene $\left(\mathrm{CO} / \mathrm{H}_{2}, 1 / 1 ;[3]=1.0 \mathrm{mM}\right.$, [trans-oct-2-ene $\left.] /\left[\mathrm{Rh}_{2}\right]=600\right) . \mathrm{GC}$ analyses of the liquid phase runs showed internal oct-n-ene olefins, nonanal (linear aldehyde), 2-methyloctanal, 2-ethyl-heptanal and 2-propyl-hexanal (internal aldehydes), and traces of oct-1-ene and octane. The results of the catalytic hydroformylation of trans-oct-2-ene by complex $\left[\mathrm{Rh}_{2}\left(\mu-\mathrm{S}_{2} \mathrm{CBn}_{2}\right)(\mathrm{cod})_{2}\right](3)$ are summarized in Table 7.

$<$ Table 7, about here>

The hydroformylation of trans-oct-2-ene $\left(\mathrm{P}\left(\mathrm{CO} / \mathrm{H}_{2}\right)=6.8\right.$ atm at $\left.80{ }^{\circ} \mathrm{C}\right)$ with a $\mathrm{P}(\mathrm{OPh})_{3} / \mathrm{Rh}=4$ ratio gave a $22 \%$ of linear aldehyde after $18 \mathrm{~h}$ (run 54 ). An increase of the temperature to $100{ }^{\circ} \mathrm{C}$ resulted in an improvement of the regioselectivity up to $44 \%$ at the same level of conversion in $8 \mathrm{~h}$, along with a decrease in the aldehyde selectivity (21.8 \%, run 55). Interestingly, the aldehyde selectivity can be improved by increasing the $\mathrm{P}(\mathrm{OPh})_{3} / \mathrm{Rh}$ ratio (runs 56 and 57$)$. The optimal value has been determined to be $\mathrm{P}(\mathrm{OPh})_{3} / \mathrm{Rh}=10$ giving $\operatorname{TOF}($ Ald $)$ values of $28 \mathrm{~h}^{-1}$. The positive influence of the temperature on the regioselectivity can be explained by the faster isomerization of the internal oct-n-ene olefins. Actually, a regioselectivity of $49 \%$ was attained when the reaction was conducted at a $120{ }^{\circ} \mathrm{C}$ (run 61) although a drastic drop in the hydroformylation activity was observed probably due to the instability of the catalytic intermediates at high temperatures. It fact, the dark colour of the resulting catalytic solution contrasts with the light bright colour obtained under milder experimental conditions.

The effect of the gradual increase of the pressure at $100{ }^{\circ} \mathrm{C}$ using a $\mathrm{P}(\mathrm{OPh})_{3} / \mathrm{Rh}=10$ ratio can be observed in runs $56,58-59$, and 60 . The pressure strongly affects the hydroformylation activity and the better aldehyde selectivity of $64.1 \%$ and TOF(Ald) of $42 \mathrm{~h}^{-1}$ was obtained at the highest pressure (13.6 atm, run 
60). However, the regioselectivity under these conditions is low (29\%) suggesting a significant hydroformylation of the internal oct-n-enes. As expected, the improvement of the regioselectivity requires low pressures. Up to $54 \%$ of linear aldehyde was attained at 2 atm (run 58) although the activity was certainly low under these conditions $\left(3 \mathrm{~h}^{-1}\right)$.

\subsection{High-Pressure NMR and IR studies}

In order to ascertain the nuclearity of the active species when using dinuclear gem-dithiolato rhodium(I) complexes as catalyst precursors for the hydroformylation of oct-1-ene, the catalytic systems $\left[\mathrm{Rh}_{2}\left(\mu-\mathrm{S}_{2} \mathrm{CBn}_{2}\right)(\mathrm{cod})_{2}\right](3) / \mathrm{P}(\mathrm{OMe})_{3}$ and $\left[\mathrm{Rh} \mathrm{h}_{2}(\mu-\right.$ $\left.\left.\mathrm{S}_{2} \mathrm{CBn}_{2}\right)(\mathrm{cod})_{2}\right](3) / \mathrm{PPh}_{3}$ have been investigated in situ using high-pressure spectroscopic techniques (HPNMR and HPIR).

A solution of complex $\left[\mathrm{Rh}_{2}\left(\mu-\mathrm{S}_{2} \mathrm{CBn}_{2}\right)(\mathrm{cod})_{2}\right](3)(25 \mathrm{mM})$ and an excess of $\mathrm{P}(\mathrm{OMe})_{3}(200 \mathrm{mM}, \mathrm{P} / \mathrm{Rh}=4$ molar ratio $)$ in toluene- $d_{8}$ was pressurized under $6.2 \mathrm{~atm}$ of a $1: 1$ mixture of $\mathrm{H}_{2} / \mathrm{CO}$ and shaken for $1 \mathrm{~h}$ at $80^{\circ} \mathrm{C}$. The ${ }^{31} \mathrm{P}\left\{{ }^{1} \mathrm{H}\right\} \mathrm{NMR}$ recorded at room temperature (Figure 7, a) showed the presence of three main species. The doublet at $\delta 163.19 \mathrm{ppm}\left(J_{\mathrm{Rh}-\mathrm{P}}=212 \mathrm{~Hz}\right)$ corresponds to the mononuclear hydride compound $\left[\mathrm{HRh}(\mathrm{CO})\left\{\mathrm{P}(\mathrm{OMe})_{3}\right\}_{3}\right]$ (9) which exhibited a characteristic quartet of doublets resonance at $\delta-10.9 \mathrm{ppm}\left({ }^{2} J_{\mathrm{P}-\mathrm{H}}=10.0 \mathrm{~Hz}\right.$ and $\left.J_{\mathrm{Rh}-\mathrm{H}}=6.8 \mathrm{~Hz}\right)$ in the high field region of the ${ }^{1} \mathrm{H}$ NMR spectrum. Both, the multiplicity and the observed coupling constants are in good agreement with those reported for the related complex $\left[\mathrm{RhH}(\mathrm{CO})\left\{\mathrm{P}(\mathrm{OEt})_{3}\right\}_{3}\right]\left({ }^{2} J_{\mathrm{P}-\mathrm{H}}=16 \mathrm{~Hz}, J_{\mathrm{Rh}-\mathrm{H}}=8 \mathrm{~Hz}\right)[29]$. The second species has been identified as the mononuclear phosphonate complex $\left[\mathrm{Rh}\left\{\mathrm{P}(\mathrm{O})(\mathrm{OMe})_{2}\right\}(\mathrm{CO})\left\{\mathrm{P}(\mathrm{OMe})_{3}\right\}_{3}\right](\mathbf{1 0})$ which exhibits a $\mathrm{A}_{3} \mathrm{MX}(\mathrm{X}=\mathrm{Rh})$ type spin system. The A part of the spectrum consists of a doublet of doublets at $\delta 145.24 \mathrm{ppm}$ 
$\left(J_{\mathrm{Rh}-\mathrm{P}}=187.9 \mathrm{~Hz}\right)$ and correspond to the equivalent phosphite ligands, whereas the M part correspond to the phosphonate group and consists of a quarted of doublets at $\delta 81.86 \mathrm{ppm}\left(J_{\mathrm{Rh}-\mathrm{P}^{\prime}}=105.0 \mathrm{~Hz}, J_{\mathrm{P}-\mathrm{P}^{\prime}}=161.1 \mathrm{~Hz}, \mathrm{P}^{\prime}=\mathrm{P}(\mathrm{O})(\mathrm{OMe})_{2}\right)$. Finally, the set of resonances at $\delta 144.40 \mathrm{ppm}(\mathrm{dd})$ and $71.71 \mathrm{ppm}(\mathrm{td})\left(J_{\mathrm{Rh}-\mathrm{P}}=166.4 \mathrm{~Hz}, J_{\mathrm{Rh}-\mathrm{P}^{\prime}}=91.6\right.$ $\mathrm{Hz}, J_{\mathrm{P}-\mathrm{P}^{\prime}}=271.3 \mathrm{~Hz}, \mathrm{P}=\mathrm{P}(\mathrm{OMe})_{3}$ and $\left.\mathrm{P}^{\prime}=\mathrm{P}(\mathrm{O})(\mathrm{OMe})_{2}\right)$ is characteristic of a $\mathrm{A}_{2} \mathrm{MX}$ $(\mathrm{X}=\mathrm{Rh})$ type spin system and has been assigned to the bis-carbonyl phosphonate complex $\left[\mathrm{Rh}\left\{\mathrm{P}(\mathrm{O})(\mathrm{OMe})_{2}\right\}(\mathrm{CO})_{2}\left\{\mathrm{P}(\mathrm{OMe})_{3}\right\}_{2}\right](11)$. Interestingly, the spectrum did not showed any resonance attributable to dinuclear complexes $\left[R h_{2}\left(\mu-S_{2} C B n_{2}\right)(C O)_{4-}\right.$ $\left.{ }_{n}\left\{\mathrm{P}(\mathrm{OMe})_{3}\right\}_{n}\right](\mathrm{n}=1-4)$ which are the expected species to be formed under hydroformylation conditions by carbonylation of the precursor 3 and CO replacement by $\mathrm{P}(\mathrm{OMe})_{3}[16]$.

\section{$<$ Figure 7 about here $>$}

The formulation of 10 and 11 as rhodium(I) pentacoordinated mononuclear phosphonate complexes relies on several experimental observations. First, the observed chemical shift of the dimethyl phosphonate ligand in the complexes compares well with the observed for the square-planar $\left[\mathrm{Rh}\left\{\mathrm{P}(\mathrm{O})(\mathrm{OPh})_{2}\right\}\left\{\mathrm{P}(\mathrm{OPh})_{3}\right\}_{3}\right]$ $(\delta 82.30 \mathrm{ppm})[30]$ and pentacoordinated $\left[\mathrm{Rh}\left\{\mathrm{P}(\mathrm{O})(\mathrm{OMe})_{2}\right\}\left\{\mathrm{P}(\mathrm{OMe})_{3}\right\}_{4}\right](\delta 81.86 \mathrm{ppm})$ [31] related complexes. More importantly, compound $\mathbf{1 0}$ has been independently obtained, together with trace amounts of 11 , by heating a $\mathrm{C}_{6} \mathrm{D}_{6}$ solution of compound $\left[\mathrm{Rh}\left\{\mathrm{P}(\mathrm{O})(\mathrm{OMe})_{2}\right\}\left\{\mathrm{P}(\mathrm{OMe})_{3}\right\}_{4}\right]$ under a $\mathrm{CO}(\mathrm{g})(\approx 2 \mathrm{~atm})$ at $80{ }^{\circ} \mathrm{C}$ for $4 \mathrm{~h}$.

When the same experiment was carried out in the presence of oct-1-ene (250 $\mathrm{mM}$ ) under the same experimental conditions, the formation of aldehydes was observed in the ${ }^{1} \mathrm{H}$ NMR spectrum at room temperature and the recorded ${ }^{31} \mathrm{P}\left\{{ }^{1} \mathrm{H}\right\}$ NMR was identical to the obtained before. This fact suggest that the Wilkinson type complex $\left[\mathrm{HRh}(\mathrm{CO})\left\{\mathrm{P}(\mathrm{OMe})_{3}\right\}_{3}\right](9)$ is the active species under this conditions. As far 
as the fate of the dithiolato ligand is concerned, some clues were obtained from the ${ }^{31} \mathrm{P}\left\{{ }^{1} \mathrm{H}\right\}$ NMR spectrum obtained after depressurization (Figure $7, \mathrm{~b}$ ) that showed the disappearance of the resonances due to complex 11 , that probably evolves to 10 under low carbon monoxide concentration, and also a significant reduction of the intensity of the resonance of $\left[\mathrm{HRh}(\mathrm{CO})\left\{\mathrm{P}(\mathrm{OMe})_{3}\right\}_{3}\right](\mathbf{9})$ that became now a residual species along with $\left[\mathrm{HRh}\left\{\mathrm{P}(\mathrm{OMe})_{3}\right\}_{4}\right](12)\left(\delta 161.95 \mathrm{ppm}, J_{\mathrm{Rh}-\mathrm{P}}=210.5 \mathrm{~Hz}\right)$ [32]. In fact, the high field region of the ${ }^{1} \mathrm{H}$ NMR spectrum showed the presence of 9 and 12 $\left(\delta-11.76 \mathrm{ppm}\right.$, quintet of doublets, $J_{\mathrm{P}-\mathrm{H}}=35.6 \mathrm{~Hz}, J_{\mathrm{Rh}-\mathrm{H}}=9.6 \mathrm{~Hz}$ ) approximately in the same ratio (Figure 8). This observation points out to the probable involvement of the free gem-dithiol compound, $\mathrm{Bn}_{2} \mathrm{C}(\mathrm{SH})_{2}$, in the disappearance of compound 9.

<Figure 8 about here>

This possibility was investigated by using the complex $\left[\mathrm{HRh}(\mathrm{CO})\left(\mathrm{PPh}_{3}\right)_{3}\right]$. Thus, we have found that the reaction of $\mathrm{Bn}_{2} \mathrm{C}(\mathrm{SH})_{2}$ with two mol-equiv. of $\left[\mathrm{HRh}(\mathrm{CO})\left(\mathrm{PPh}_{3}\right)_{3}\right]$ in $\mathrm{C}_{6} \mathrm{D}_{6}$ at room temperature resulted mainly in the formation of the dinuclear compound $\left[\mathrm{Rh}_{2}\left(\mu-\mathrm{S}_{2} \mathrm{CBn}{ }_{2}\right)(\mathrm{CO})_{2}\left(\mathrm{PPh}_{3}\right)_{2}\right](7)$ and 1,3-diphenyl-propane2-thiol in roughly 1:2 ratio, together with other unidentified species. The thiol compound, $\mathrm{Bn}_{2} \mathrm{CH}(\mathrm{SH})$, has been identified by NMR $\left({ }^{1} \mathrm{H}\right.$ and ${ }^{1} \mathrm{H}-{ }^{1} \mathrm{H}$ COSY $)$ [33] and detected by GC/MS. The chemical shifts and coupling constants observed in the ${ }^{1} \mathrm{H}$ NMR spectrum compare well with those reported for other 1-arylpropan-2-thiol derivatives or its compounds [34]. It is know that some gem-dithiol compounds are unstable against the lost of $\mathrm{SH}_{2}(\mathrm{~g})$ to give the corresponding thione [35]. In the present case, the rhodium-mediated decomposition of $\mathrm{Bn}_{2} \mathrm{C}(\mathrm{SH})_{2}$ and the hydrogenation of the resulting thione $\mathrm{Bn}_{2} \mathrm{C}=\mathrm{S}$ by two equivalents of [HRh(CO)(PPh$\left.)_{3}\right]$ could account for the formation of $\mathrm{Bn}_{2} \mathrm{CH}(\mathrm{SH})$. Evidently, this is a competitive process with the formation of 7 and $\mathrm{H}_{2}(\mathrm{~g})$ elimination. 
The product distribution observed in the system $\left[\mathrm{Rh}_{2}\left(\mu-\mathrm{S}_{2} \mathrm{CBn}\right)(\operatorname{cod})_{2}\right]$ $(3) / \mathrm{P}(\mathrm{OMe})_{3}$ under hydroformylation conditions (Scheme 2) can be also obtained sequentially starting from $[\mathrm{Rh}(\mathrm{acac})(\mathrm{cod})]$. Thus, a solution of $[\mathrm{Rh}(\mathrm{acac})(\mathrm{cod})]$ in the presence of $\mathrm{P}(\mathrm{OMe})_{3}(1: 4)$ under $\mathrm{H}_{2}(\mathrm{~g})(\approx 2 \mathrm{bar})$ in $\mathrm{C}_{6} \mathrm{D}_{6}$ at $80{ }^{\circ} \mathrm{C}$ for $3 \mathrm{~h}$ gave the complex $\left[\mathrm{HRh}\left\{\mathrm{P}(\mathrm{OMe})_{3}\right\}_{4}\right]$. Further heating of the solution under $\mathrm{CO}(\mathrm{g})(\approx 2$ bar $)$ at 80 ${ }^{\circ} \mathrm{C}$ for $1 \mathrm{~h}$ gave a mixture of the complexes $\left[\mathrm{HRh}(\mathrm{CO})\left\{\mathrm{P}(\mathrm{OMe})_{3}\right\}_{3}\right]$ (9) (63\%), $\left[\mathrm{HRh}\left\{\mathrm{P}(\mathrm{OMe})_{3}\right\}_{4}\right](12)(30 \%)$ and $\left.\left[\mathrm{Rh}\left\{\mathrm{P}(\mathrm{O})(\mathrm{OMe})_{2}\right\} \mathrm{P}(\mathrm{OMe})_{3}\right\}_{4}\right](10)(27 \%)$. Further reaction with $\mathrm{Bn}_{2} \mathrm{C}(\mathrm{SH})_{2}$ resulted in the disappearance 9 and 12 and the formation of 1,3-diphenyl-propane-2-thiol.

\section{$<$ Scheme 2, about here $>$}

The hydroformylation of oct-1-ene with the catalytic system $\left[\operatorname{Rh}_{2}(\mu-\right.$ $\left.\left.\mathrm{S}_{2} \mathrm{CBn}_{2}\right)(\mathrm{cod})_{2}\right](\mathbf{3}) / \mathrm{PPh}_{3}$ has also been studied in situ by HPNMR. Thus, a solution of complex $\left[\mathrm{Rh}_{2}\left(\mu-\mathrm{S}_{2} \mathrm{CBn}_{2}\right)(\mathrm{cod})_{2}\right](3)(12 \mathrm{mM})$ and an excess of $\mathrm{PPh}_{3}(96 \mathrm{mM}, \mathrm{P} / \mathrm{Rh}=$ 4 molar ratio) in toluene- $d_{8}$ was pressurized under $6.2 \mathrm{~atm}$ of a $1: 1$ mixture of $\mathrm{H}_{2} / \mathrm{CO}$ and heated for $1 \mathrm{~h}$ at $80^{\circ} \mathrm{C}$. The ${ }^{31} \mathrm{P}\left\{{ }^{1} \mathrm{H}\right\} \mathrm{NMR}$ recorded at room temperature showed exclusively the presence of $\left[\mathrm{Rh}_{2}\left(\mu-\mathrm{S}_{2} \mathrm{CBh}_{2}\right)(\mathrm{CO})_{2}\left(\mathrm{PPh}_{3}\right)_{2}\right](7)\left(\delta 40.88 \mathrm{ppm}, J_{\mathrm{Rh}-\mathrm{P}}=\right.$ $162 \mathrm{~Hz}$, trans isomer) and $\mathrm{PPh}_{3}(\delta-5.0 \mathrm{ppm})$. As expected, compound 7 was formed by carbonylation of 3 and $\mathrm{CO}$ replacement by $\mathrm{PPh}_{3}$, a process that also take place at $1 \mathrm{~atm}$ of $\mathrm{CO}(\mathrm{g})$. After heating for $2.5 \mathrm{~h}$ the high field region of the ${ }^{1} \mathrm{H}$ NMR spectrum showed a tiny resonance at $\delta-9.2$ ppm although no new species different from 7 were observed in the ${ }^{31} \mathrm{P}\left\{{ }^{1} \mathrm{H}\right\}$ NMR. The addition of oct-1-ene $(120 \mathrm{mM})$ and heating for and additional period of $2 \mathrm{~h}$ resulted in the formation of aldehydes and in the disappearance of the hydride resonance. When the reaction was conducted in the presence of oct-1-ene, under the same conditions, aldehydes were formed in $1 \mathrm{~h}$, although prolonged heating was necessary in order to detect the species 
$\left[\mathrm{HRh}(\mathrm{CO})_{2}\left(\mathrm{PPh}_{3}\right)_{2}\right](13)\left(\delta 37.3 \mathrm{ppm}, J_{\mathrm{Rh}-\mathrm{P}}=138.7 \mathrm{~Hz}\right)[36]$ in the ${ }^{31} \mathrm{P}\left\{{ }^{1} \mathrm{H}\right\} \mathrm{NMR}(13 \mathrm{~h}$, $<1 \%)$.

The outstanding stability of $\left[\mathrm{Rh}_{2}\left(\mu-\mathrm{S}_{2} \mathrm{CBn}{ }_{2}\right)(\mathrm{CO})_{2}\left(\mathrm{PPh}_{3}\right)_{2}\right]$ (7) under hydroformylation conditions contrast with the complete degradation of complexes $\left[\mathrm{Rh}_{2}\left(\mu-\mathrm{S}_{2} \mathrm{CBn}_{2}\right)(\mathrm{CO})_{4-n}\left\{\mathrm{P}(\mathrm{OMe})_{3}\right\}_{\mathrm{n}}\right](\mathrm{n}=1-4)$ into several mononuclear species. In order to determine if the compound $\left[\mathrm{HRh}(\mathrm{CO})_{2}\left(\mathrm{PPh}_{3}\right)_{2}\right](13)$ is the responsible for the catalytic activity of the system $\left[\mathrm{Rh}_{2}\left(\mu-\mathrm{S}_{2} \mathrm{CBn}\right)_{2}(\mathrm{cod})_{2}\right](3) / \mathrm{PPh}_{3}$, we carried out the characterization of this system in situ by IR spectroscopy under the reaction conditions used in the catalytic hydroformylation experiments (HPIR).

A solution of complex $\left[\mathrm{Rh}_{2}\left(\mu-\mathrm{S}_{2} \mathrm{CBn}_{2}\right)(\mathrm{cod})_{2}\right](3)(1 \mathrm{mM})$ and $\mathrm{PPh}_{3}(8 \mathrm{mM}$, $\mathrm{P} / \mathrm{Rh}=4$ molar ratio) in 2-methyltetrahydrofuran was pressurized under $6.2 \mathrm{~atm}$ of a 1:1 mixture of $\mathrm{H}_{2} / \mathrm{CO}$ and stirred for $1 \mathrm{~h}$ at $80^{\circ} \mathrm{C}$. The IR spectrum (Figure 9 ) features a strong absorption at $v(\mathrm{CO}) 1965 \mathrm{~cm}^{-1}$ that correspond to the dinuclear complex 7 . However, the spectrum also shows other absorptions of smaller intensity at $\{(\mathrm{CO})$ 2053, 2043, 1992, 1981, 1973 and $1948 \mathrm{~cm}^{-1}$. The absorptions at 2043, 1992, 1981 and $1948 \mathrm{~cm}^{-1}$ are attributed to the compound $\left[\mathrm{HRh}(\mathrm{CO})_{2}\left(\mathrm{PPh}_{3}\right)_{2}\right](13)$ which exits as two trigonal-bipyramidal isomers in equilibrium. The bands at 1992 and $1948 \mathrm{~cm}^{-1}$ are assigned to the isomer having hydride and triphenylphosphine ligands in the apical positions (13a) whereas that the bands at 2043 and $1981 \mathrm{~cm}^{-1}$ are attributed to isomer having hydride and carbonyl ligands in the apical positions (13b) [15c, 37]. Finally, the pentacoordinated dinuclear compound $\left[\mathrm{Rh}_{2}\left(\mu-\mathrm{S}_{2} \mathrm{CBn}_{2}\right)(\mathrm{CO})_{4}\left(\mathrm{PPh}_{3}\right)_{2}\right](\mathbf{1 4})$ (Scheme 3) probably accounts for the rest of absorptions at 2053 and $1973 \mathrm{~cm}^{-1}$ [15c, 38].

<Figure 9 and Scheme 3, about here> 


\subsection{Kinetic study of oct-1-ene hydroformylation}

The progress of the oct-1-ene hydroformylation by the catalytic systems $\left[\mathrm{Rh}_{2}\left(\mu-\mathrm{S}_{2} \mathrm{CBn}_{2}\right)(\operatorname{cod})_{2}\right] \quad(3) / \mathrm{P}(\mathrm{OMe})_{3} \quad$ and $\quad\left[\mathrm{Rh}_{2}\left(\mu-\mathrm{S}_{2} \mathrm{CBn}_{2}\right)(\operatorname{cod})_{2}\right] \quad(3) / \mathrm{PPh}_{3}$ was monitored by pressure drop measurements. The consumption of $\mathrm{H}_{2} / \mathrm{CO}(\mathrm{g})$ was registered as a pressure decrease in the ballast that maintains a constant pressure in the autoclave by means of a pressure transmitter at intervals of 3 min. Figure 10 shows the pressure vs time plot for the course of the oct-1-ene hydroformylation for both systems under the same experimental conditions: $[3]=1.35 \mathrm{mM},\left[\mathrm{PR}_{3}\right]=10.8$ $\mathrm{mM}(\mathrm{P} / \mathrm{Rh}=4$ molar ratio $)$ [oct-1-ene] $=600 \mathrm{mM}, \mathrm{P}\left(\mathrm{CO} / \mathrm{H}_{2}\right)=6.8 \mathrm{~atm}$ and $80^{\circ} \mathrm{C}$. The plot evidenced the existence of an induction period for both catalytic systems: $18 \mathrm{~min}$ for $3 / \mathrm{P}(\mathrm{OMe})_{3}$ and $39 \mathrm{~min}$ for $3 / \mathrm{PPh}_{3}$. However, the activity of both systems, estimated as the rate of pressure drop from the linear part of the plot pressure vs time after the induction period, is roughly the same $\left(3.8 \times 10^{-3} \mathrm{bar} / \mathrm{min}\right)$. This fact suggests that the mononuclear species $\left[\mathrm{HRh}(\mathrm{CO})_{2}\left(\mathrm{PPh}_{3}\right)_{2}\right]$ is far more active than $\left[\mathrm{HRh}(\mathrm{CO})\left\{\mathrm{P}(\mathrm{OMe})_{3}\right\}_{3}\right]$ because the concentration of the former is much smaller under the same hydroformylation conditions (HPMNR evidence). It is interesting to note that the observed induction period in the system $3 / \mathrm{PPh}_{3}$ is very much dependent on the concentration of the catalyst precursor. Thus, the induction period was increased from 39 to $81 \mathrm{~min}$ by a decrease in the precursor concentration from $1.35 \mathrm{mM}$ to 1.00 $\mathrm{mM}$.

$<$ Figure 10 about here>

In order to confirm the involvement of mononuclear compounds as the active catalytic species in the system $3 / \mathrm{PPh}_{3}$, the dependence of the hydroformylation rate on the concentration of $\left[\mathrm{Rh}_{2}\left(\mu-\mathrm{S}_{2} \mathrm{CBn}_{2}\right)(\operatorname{cod})_{2}\right]$ (3) was investigated. The pressure 
decrease was converted into moles of aldehyde by using the pre-calibrated volume of the system and considering ideal gas behavior [39]. Thus, a series of catalytic runs with concentrations of 3 in the range $0.18-2.00 \mathrm{mM}, \mathrm{PPh}_{3}(\mathrm{P} / \mathrm{Rh}=4$ molar ratio), [oct1-ene $]=600 \mathrm{mM}, \mathrm{P}\left(\mathrm{CO} / \mathrm{H}_{2}\right)=6.8 \mathrm{~atm}$ and $80{ }^{\circ} \mathrm{C}$ have been carried out. The initial reaction rates $\left(\mathrm{mol} \mathrm{s}^{-1}\right)$ were determined from the mol of aldehydes $v s$ time plots at $10 \%$ of conversion. Figure 11 shows the logarithmic representation of these initial rates as a function of the initial precursor concentration $\left(\mathrm{mol} \mathrm{L}^{-1}\right)$. The least-square fit indicate half-order dependence of the reaction rate on the rhodium dimer concentration $\left(R^{2}=0.95\right)$, which confirm the participation of active mononuclear species (Scheme 3).

<Figure 11 about here>

\section{Discussion}

The results described in the precedent sections show marked tendencies in the activity, selectivity and regioselectivity that are very much dependent both on the gem-dithiolato bridging ligand and the P-donor ligand used as co-catalyst. However, high-pressure spectroscopic techniques (HPNMR and HPIR) have revealed that mononuclear species formed under catalytic conditions are most probably responsible for the observed catalytic activity.

The activity of the different catalytic systems is strongly influenced by the gemdithiolato ligand although the effect both on the selectivity and regioselectivity is rather small. In general, the precursors containing acyclic gem-dithiolato ligands, $\left[\mathrm{Rh}_{2}\left(\mu-\mathrm{S}_{2} \mathrm{CBn}_{2}\right)(\mathrm{cod})_{2}\right](3)$ and $\left[\mathrm{Rh}_{2}\left(\mu-\mathrm{S}_{2} \mathrm{C}^{\prime} \mathrm{Pr}_{2}\right)(\mathrm{cod})_{2}\right](4)$, are more active than the precursors with cyclic ligands $\left[\operatorname{Rh}_{2}\left(\mu-S_{2} \operatorname{Cptn}\right)(\operatorname{cod})_{2}\right](\mathbf{1})$ and $\left[R h_{2}\left(\mu-S_{2} C h x n\right)(\operatorname{cod})_{2}\right]$ 
(2). The maximum activity for the four catalytic systems based on $\mathrm{P}(\mathrm{OMe})_{3}$ was found at the ratio $\mathrm{P} / \mathrm{Rh}=4$ (reaction time $2 \mathrm{~h}$ ) and the observed activity order is $4>\mathbf{3}>\mathbf{2}>$ 1. Interestingly, the same activity order was found in the systems based on $\mathrm{PPh}_{3}$ at the ratio $\mathrm{P} / \mathrm{Rh}=4$ (reaction time $6 \mathrm{~h}$ ) although the activity gap between 2 and 1 is now considerable. However, the activity of the systems based on $\mathrm{P}(\mathrm{OPh})_{3}$ decreases in the series $4>2>3>1$ at $\mathrm{P} / \mathrm{Rh}=6$ (reaction time $2 \mathrm{~h}$ ).

The lower activity of the systems based on dinuclear precursors having cyclic gem-dithiolato ligands could be related to the higher stability of the dinuclear framework toward cleavage into active mononuclear hydrido species under the hydroformylation conditions. However, the activity is also influenced by the P/Rh ratio and the type of P-donor ligand used as cocatalyst. In general, the systems involving phosphite ligands, $\mathrm{P}(\mathrm{OR})_{3}$, are much more active than the based on $\mathrm{PPh}_{3}$ irrespective of the catalytic precursor. In fact, reaction times of at least 6 hours were necessary in order to get acceptable conversions when $\mathrm{PPh}_{3}$ was used as cocatalyst, although excellent conversions were attained in only two hours in the case of $\mathrm{P}(\mathrm{OR})_{3}$ ligands. These results contrast with the behaviour observed for neutral and cationic dinuclear complexes with standard thiolato ligands since the catalytic systems involving $\mathrm{PPh}_{3}$ as co-catalyst are far more active than the based on $\mathrm{P}(\mathrm{OR})_{3}$ ligands $[23,40,41]$. However, the performance of the precursor $\left[\operatorname{Rh}_{2}(\mu-\right.$ $\left.\mathrm{S}\left(\mathrm{CH}_{2}\right)_{n} \mathrm{~S}\right)(\mathrm{cod})_{2}$ ] is very similar when using $\mathrm{PPh}_{3}$ or $\mathrm{P}(\mathrm{OR})_{3}$ as co-catalyst [42].

These results indicate that the activity of the catalytic systems is not directly correlated with the electronic properties of the P-donor ligands as the basicity of $\mathrm{P}(\mathrm{OMe})_{3}$ and $\mathrm{PPh}_{3}$ are comparable ( $\mathrm{pK}_{\mathrm{a}}$ of 2.6 and 2.73 , respectively) being $\mathrm{P}(\mathrm{OPh})_{3}$ the less basic ligand in this series $\left(\mathrm{pK}_{\mathrm{a}}\right.$ of -2.0$)$ [43]. The excellent activity of the systems based on $\mathrm{P}(\mathrm{OR})_{3}$ ligands is probably associated to the higher concentration 
of the active mononuclear hydrido species which is strongly supported by the HPNMR and HPIR spectroscopic studies carried out on the systems $3 / \mathrm{P}(\mathrm{OMe})_{3}$ and $3 / \mathrm{PPh}_{3}$. On the other hand, the formation of the active species from dinuclear precursors requires the presence of a significant concentration of P-donor ligand. Thus, the influence of the P/Rh ratio in the activity is most likely related with the concentration of the active species under hydroformylation conditions.

The main difference between these modifying ligands concerns the aldehyde selectivity. In general, aldehyde selectivities higher than $95 \%$ and $90 \%$ were obtained with the catalytic systems involving $\mathrm{P}(\mathrm{OMe})_{3}$ and $\mathrm{PPh}_{3}$, respectively. However, lower selectivities were observed with the catalytic systems based on $\mathrm{P}(\mathrm{OPh})_{3}$ as a consequence of the high isomerization activity that is about $20 \%$ in most cases. It is well know that the complex $\left[\mathrm{HRh}(\mathrm{CO})\left\{\mathrm{P}(\mathrm{OPh})_{3}\right\}_{3}\right]$ is the active species for hydroformylation of rhodium catalytic systems involving $\mathrm{P}(\mathrm{OPh})_{3}$ [44] which exhibited high isomerization activity that has been attributed both to the participation of the species $\left[\mathrm{HRh}\left\{\mathrm{P}(\mathrm{OPh})_{3}\right\}_{4}\right][45]$ and rhodium-carbonyl clusters [46]. These results suggest the participation of mononuclear hydrido species as the active species for the hydroformylation of oct-1-ene also in these systems.

Further support for the involvement of active mononuclear hydrido species comes from the observed regioselectivities that seem to be mainly determined by the nature of the P-donor ligand suggesting the participation of the same active species. Typical regioselectivities for $\mathrm{P}(\mathrm{OPh})_{3}$ and $\mathrm{P}(\mathrm{OMe})_{3}$, using a $\mathrm{P} / \mathrm{Rh}=6$ ratio, are $84 \%$ and $82 \%$, respectively. Under the same conditions, the catalytic systems based on $\mathrm{PPh}_{3}$ gave lower regioselectivities: 80\% (precursor 1 and 3 ) and $75 \%$ (precursors 2 and 4). 


\section{Conclusions}

Dinuclear gem-dithiolato-bridged $\left[\mathrm{Rh}_{2}\left(\mu-\mathrm{S}_{2} \mathrm{CR}_{2}\right)(\mathrm{cod})_{2}\right]$ complexes in the presence of P-donor ligands are active catalyst precursors for the hydroformylation of oct-1-ene under mild conditions. The catalytic studies carried out with several Pdonor modifying ligands and four different catalytic precursors have shown the systems involving phosphite ligands, $\mathrm{P}(\mathrm{OR})_{3}$, are much more active than the based on $\mathrm{PR}_{3}$. However, the activity is strongly dependent on the catalyst precursor, and consequently on the structure of the dinuclear complexes, although it is also influenced by the P/Rh ratio. In general, catalytic precursors containing acyclic gemdithiolato ligands are more active than the precursors with cyclic ligands. The selectivitiy and regioselectivy are mainly determined by the P-donor ligands, although there is not a clear correlation between both parameters and the electronic and steric properties of the co-catalyst. Spectroscopic studies under pressure (HPNMR and HPIR) showed that hydrido mononuclear species formed under catalytic conditions are presumably responsible for the observed catalytic activity.

\section{Acknowledgments}

The financial support from Ministerio de Educación y Ciencia (MEC/FEDER) Project CTQ2006-03973/BQU is gratefully acknowledged. A. B. R. thanks the Programa Iberoamericano de Ciencia y Tecnología para el Desarrollo (CYTED) for a fellowship. A. B. R. and A. J. P. thank to Fonacit-Venezuela (S1-2002000260) for financial support. 


\section{References}

[1] B. Cornils, W.A. Herrmann (Eds.), Applied Homogeneous Catalysis with Organometallic Compounds, $2^{\text {nd }}$ ed., Wiley-VCH, Weinheim, 2002.

[2] J.L. Leighton, in: Modern Rhodium-Catalyzed Organic Reactions, P.A. Evans (Ed.), Wiley-VCH, Weinheim, 2005, Chap. 5, pp. 93-110.

[3] P.W.N.M. van Leeuwen, C. Claver (Eds.), Rhodium Catalyzed Hydroformylation, in: B.R. James, P.W.N.M. van Leeuwen (Eds.), Catalysis by Metal Complexes Series, vol. 22, Kluwer Academic Publishers, Dordrecht, 2000.

[4] (a) J.M. Praetorius, M.W. Kotyk, J.D. Webb, R. Wang, C.M. Crudden, Organometallics 26 (2007) 1057; (b) R.A. Baber, M.F. Haddow, A.J. Middleton, A.G. Orpen, P.G. Pringle, A. Haynes, G.L. Williams, R. Papp, Organometallics 26 (2007) 713; (c) D. Rivillo, H. Gulyás, J. Benet-Buchholz, E. C. EscuderoAdán, Z. Freixa, P.W.N M. van Leeuwen, Angew. Chem. Int. Ed. 46 (2007) 7247; (d) E. Fuchs, M. Keller, B. Breit, Chem. Eur. J. 12 (2006) 6930; (e) A. Moores, N. Mezailles, L. Ricard, P. Le Floch, Organometallics 24 (2005) 508; (f) M. Beller, B. Cornils, C.D. Frohning, C.W. Kohlpaintner, J. Mol. Catal. A: Chem. $104(2002) 17$.

[5] M. Shibasaki, Y. Yamamoto, (Eds.), Multimetallic Catalysts in Organic Synthesis, Wiley-VCH, Weinheim, 2004.

[6] P. Braunstein, J. Rosé, in Comprehensive Organometallic Chemistry II, E.W. Abel, F. G. A. Stone, G. Willkinson, Eds. Elsevier Science Ltd.: Oxford, 1995, Vol. 10, Chap. 7, pp. 351-385. 
[7] R.D. Adams, F.A. Cotton (Eds.), Catalysis by Di- and Polynuclear Metal Cluster Complexes, Wiley-VCH, New York, 1998.

[8] N. Wheatly, P. Kalck, Chem. Rev. 99 (1999) 3379.

[9] (a) M. Yamane, N. Yukimura, H. Ishiai, K. Narasaka, Chemistry Letters 35 (2006) 540; (b) P.J. Baricelli, F. López-Linares, A. Bruss, R. Santos, E. Lujano, R. A. Sánchez-Delgado, J. Mol. Catal. A: Chem. 239 (2005) 130; (c) M.A. Rida, A.K. Smith, J. Mol. Catal. A: Chem. 202 (2003) 87; (d) M. Poyatos, P. Uriz, J.A. Mata, C. Claver, E. Fernandez, E. Peris, Organometallics 22 (2003) 440; (e) R.S. Dickson, J. Bowen, E.M. Campi, W.R. Jackson, C.A.M. Jonasson, F.J. McGrath, D.J. Paslow, A. Polas, P. Renton, S. Gladiali, J. Mol. Catal. A: Chem. 150 (1999) 133; (f) L. Geimini, D.W. Stephan, Organometallics 7 (1988) 849.

[10] (a) G.G. Stanley, in: Multimetallic Catalysts in Organic Synthesis; M. Shibasaki, Y. Yamamoto (Eds.), Wiley-VCH: Weinheim, 2004, Chap. 10, pp. 225-248; (b) M.E. Brousand, B. Juma, S.G. Train, W. -J. Peng, S.A. Laneman, G.G. Stanley, Science 260 (1993) 1784; (c) R.C. Matthews, D.K. Howell, W.-J. Peng, S.G. Train, W. Dale-Treleaven, G.G. Stanley, Angew. Chem., Int. Ed. Engl. 35 (1996) 2253.

[11] E.K. Van der Beuken, B.L. Feringa, Tetrahedron 54 (1998) 12985.

[12] (a) P. Kalck, J.M. Frances, P.M. Pfister, T.G. Southern, A. Thorez, J. Chem. Soc. Chem. Commun. (1983) 510; (b) P. Kalck in: Organometallics in Organic Syntheses; A. de Meijere, H. Tom Dick, (Eds.), Springer Verlag, Weinheim, 1987, p. 297; (c) P. Kalck, Pure Appl. Chem. 61 (1989) 967; (d) P. Kalck, Polyhedron 7 (1988) 2441; (e) F. Monteil, R. Queau, P. Kalck, J. Organomet. Chem. 480 (1994) 177. 
[13] J.C. Bayón, C. Claver, A.M. Masdeu-Bultó, Coord. Chem. Rev. 193-195 (1999) 73.

[14] R. Davis, J.W. Epton, T.G. Southern, J. Mol. Catal. A: Chem. 77 (1992) 159.

[15] (a) A. Castellanos-Páez, S. Castillón, C. Claver, P.W.N.M. van Leeuwen, W.G.J. Lange, Organometallics 17 (1998) 2543; (b) H. Gao, R.J. Angelici, Organometallics 17 (1998) 3063; (c) M. Diéguez, C. Claver, A.M. Masdeu-Bultó, A. Ruiz, P.W.N.M. van Leeuwen, G. Schoemaker, Organometallics 18 (1999) 2107; (d) J. Forniés-Cámer, A.M. Masdeu-Bultó, C. Claver, C. Tejel, M.A. Ciriano, C.J. Cardin, Organometallics 21 (2002) 2609.

[16] M.A.F. Hernandez-Gruel, G. Gracia-Arruego, A.B. Rivas, I.T. Dobrinovich, F.J. Lahoz, A.J. Pardey, L.A. Oro, J.J. Pérez-Torrente, Eur. J. Inorg. Chem. (2007) 5677.

[17] A.B. Rivas, J.M. Gascón, F.J. Lahoz, A.I. Balana, A.J. Pardey, L.A. Oro, J.J. Pérez-Torrente, Inorg. Chem. 47 (2008) 6090.

[18] M.A.F. Hernandez-Gruel, J.J. Pérez-Torrente, M.A. Ciriano, A.B. Rivas, F.J. Lahoz, I.T. Dobrinovitch, L.A. Oro, Organometallics 22 (2003) 1237.

[19] A. Cusanelli, U. Frey, D.T. Richens, A. Merbach, J. Am. Chem. Soc. 118 (1996) 5265.

[20] P. C. J. Kamer, A. Van Rooy, G. C. Schoemaker, P. W. N. M. Van Leeuwen, Coord. Chem. Rev. 248 (2004) 2409.

[21] C.A. Tolman, Chem. Rev. 77 (1977) 313.

[22] P. Kalck, A. Thorez, M.T. Pinillos, L.A. Oro, J. Mol. Catal. A: Chem. 31 (1985) 311. 
[23] J.C. Bayon, P. Esteban, J. Real, C. Claver, A. Ruiz, J. Chem. Soc. Dalton Trans. (1989) 1579.

[24] D.E. Fogg, E.N. dos Santos, Coord. Chem. Rev. 248 (2004) 2365.

[25] Y. Yan, X. Zhang, X. Zhang, J. Am. Chem. Soc. 128 (2006) 16058.

[26] D. Selent, D. Hess, K.-D. Wiese, D. Rottger, C. Kunze, A. Borner, Angew. Chem. Int. Ed. 40 (2001) 1696.

[27] (a) L.A. van der Veen, P.C.J. Kamer, P.W.N.M. van Leeuwen, Angew. Chem., Int. Ed. 38 (1999) 336; (b) H. Klein, R. Jackstell, K.-D. Wiese, C. Borgmann, M. Beller, Angew. Chem. Int. Ed. 40 (2001) 3408.

[28] (a) A. Behr, D. Obst, B. Turkowski, J. Mol. Catal. A: Chem. 226 (2005) 215; (b) C. Vogl, E. Paetzold, C. Fischer, U. Kragl, J. Mol. Catal. A: Chem. 232 (2005) 41.

[29] A.M. Trzeciak, J.J. Ziolkowski, S. Aygen, R. Van Eldik, J. Mol. Catal. 34 (1986) 337.

[30] S. Aygen, R. Van Eldik, Organometallics 6 (1987) 1080.

[31] (a) S.I. Klein, J.F. Nixon, J. Organomet. Chem. 302 (1986) 87; (b) S.I. Klein, J.F. Nixon, J. Organomet. Chem. 304 (1986) 371.

[32] A.J. Sivak, E.L. Muetterties, J. Am. Chem. Soc. 101 (1979) 4878.

[33] 1,3-diphenyl-propan-2-thiol: ${ }^{1} \mathrm{H}$ NMR $\left(\mathrm{C}_{6} \mathrm{D}_{6}\right), \delta:$ 7.35-7.08 $(\mathrm{m}, 10 \mathrm{H}, \mathrm{Ph}), 3.28$ $(\mathrm{m}, 1 \mathrm{H}, \mathrm{CH}), 2.88\left(\mathrm{dd}, 2 \mathrm{H}, \mathrm{A}\right.$ part of $\left.A B X, J_{A B}=13.6 \mathrm{~Hz}, J_{A X}=5.6 \mathrm{~Hz}\right), 2.67(\mathrm{dd}$, $2 \mathrm{H}, \mathrm{B}$ part of $\left.\mathrm{ABX}, J_{A B}=13.6 \mathrm{~Hz}, J_{A X}=8.5 \mathrm{~Hz}\right), 1.45(\mathrm{~d}, 1 \mathrm{H}, J=4.8 \mathrm{~Hz}, \mathrm{SH})$. 
[34] (a) M. Matsugi, Y. Hagimoto, K. Itoh, M. Nojima, Y. Kita, Chem. Pharm. Bull. 51 (2003) 460; (b) P.C. Cagle, O. Meyer, D. Vichard, K. Weickhardt, A.M. Arif, J.A. Gladysz, Organometallics 15 (2006) 194.

[35] (a) E. Campaigne, B.E. Edwards, J. Org. Chem. 27 (1962) 3760. (b) R. Mayer, G. Hiller, M. Nitzschke, J. Jentzsch, Angew. Chem., Int. Ed. 75 (1963) 1011.

[36] C. Bianchini, H.M. Lee, A. Meli, F. Vizza, Organometallics. 19 (2000) 849.

[37] L. A. van der Veen, M.D. Bolee, F.R. Bregman, P.C.J. Kamer, P.W.N.M. van Leeuwen, K. Goubitz, J. Fraanje, H. Schenk, C. Bo, J. Am Chem. Soc. 120 (1998) 11616.

[38] Ph. Kalck, R. Poliblanc, Inorg. Chem. 11 (1075) 2779.

[39] The hydrogenation activity $(<5 \%)$ has not been taken into account in the determination of the mol of produced aldehydes from the consumption of $\mathrm{H}_{2} / \mathrm{CO}(\mathrm{g})$. The reaction progress was checked by $\mathrm{GC}$ at the end of the reaction.

[40] J.C. Bayón, J. Real, C. Claver, A. Polo, A. Ruiz, J. Chem. Soc. Commun. (1989) 1056.

[41] J.C. Bayón, P. Esteban, J. Real, C. Claver, A. Polo, A. Ruiz, S. Castillón, J. Organomet. Chem. 403 (1991) 393.

[42] A. Aaliti, A. M. Masdeu, A. Ruiz, C. Claver, J. Organomet. Chem. 489 (1995) 101.

[43] M.M. Rahman, H.Y. Liu, K. Eriks, A. Prock, W.P. Giering, Organometallics 8 (1989) 1.

[44] A.M. Trzeciak, J. Organomet. Chem. 390 (1990) 105.

[45] A.M. Trzeciak, J.J. Ziolkowski, J. Mol. Catal. 34 (1985) 213. 
[46] A.M. Trzeciak, J.J. Ziolkowski, T. Lis, R. Choukroun, J. Organomet. Chem. 575 (1999) 87. 
Table 1

Hydroformylation of oct-1-ene by the system $\left[\mathrm{Rh}_{2}\left(\mu-\mathrm{S}_{2} \mathrm{CR}_{2}\right)(\operatorname{cod})_{2}\right] / \mathrm{P}(\mathrm{OPh})_{3}{ }^{\text {a }}$

\begin{tabular}{|c|c|c|c|c|c|c|c|}
\hline \multirow[b]{2}{*}{ Run } & \multirow[b]{2}{*}{ Precursor } & \multirow[b]{2}{*}{$\mathrm{P} / \mathrm{Rh}$} & \multirow{2}{*}{$\begin{array}{c}\text { Conversion } \\
\qquad(\%)\end{array}$} & \multicolumn{2}{|c|}{ Selectivity (\%) } & \multirow[b]{2}{*}{$n(\%)$} & \multirow[b]{2}{*}{ TOF (Ald $)^{b}$} \\
\hline & & & & Ald. & Isom. & & \\
\hline 1 & 1 & 4 & 29.6 & 74.1 & 25.8 & 78 & 66 \\
\hline 2 & 1 & 6 & 42.0 & 96.9 & 2.6 & 84 & 122 \\
\hline 3 & 1 & 8 & 82.7 & 80.6 & 18.9 & 86 & 200 \\
\hline 4 & 2 & 2 & 16.2 & 92.6 & 6.6 & 89 & 45 \\
\hline 5 & 2 & 4 & 96.5 & 76.7 & 22.7 & 83 & 222 \\
\hline 6 & 2 & 6 & 98.2 & 73.8 & 25.5 & 84 & 217 \\
\hline 7 & 3 & 2 & 25.1 & 70.1 & 28.8 & 77 & 53 \\
\hline 8 & 3 & 6 & 86.5 & 81.9 & 17.4 & 83 & 213 \\
\hline 9 & 3 & 4 & 97.3 & 78.9 & 20.0 & 80 & 230 \\
\hline 10 & $3^{c}$ & 4 & 97.3 & 42.2 & 57.8 & $77^{d}$ & 123 \\
\hline 11 & $3^{c}$ & 10 & 95.6 & 59.0 & 41.0 & $74^{e}$ & 169 \\
\hline 12 & 4 & 4 & 22.1 & 62.2 & 37.1 & 77 & 41 \\
\hline 13 & 4 & 6 & 95.9 & 79.4 & 20.0 & 85 & 228 \\
\hline 14 & 4 & 8 & 92.6 & 80.9 & 18.8 & 84 & 225 \\
\hline
\end{tabular}

${ }^{a}$ Reaction conditions: oct-1-ene (1.6 mL, $\left.10.2 \mathrm{mmol}, 0.6 \mathrm{M}\right)$, toluene $(15.4 \mathrm{~mL})$, $\left[\mathrm{Rh}_{2}\left(\mu-\mathrm{S}_{2} \mathrm{CR}_{2}\right)(\mathrm{cod})_{2}\right](0.017 \mathrm{mmol}, 1.0 \mathrm{mM})$, [oct-1-ene $] /\left[\mathrm{Rh}_{2}\right]=600, \mathrm{P}=6.8 \mathrm{~atm}$ $\left(\mathrm{CO} / \mathrm{H}_{2}, 1 / 1\right)$ at $80^{\circ} \mathrm{C}$ for $2 \mathrm{~h}$.

${ }^{\mathrm{b}} \mathrm{TOF}(\mathrm{Ald})=\mathrm{mol}$ of aldehyde $[\mathrm{mol} \text { of catalyst }]^{-1} \mathrm{~h}^{-1}$ corresponds to the reaction time (t).

${ }^{\mathrm{c}} \mathrm{T}=100^{\circ} \mathrm{C}$.

d 2-methyl-octanal 21\%, 2-ethyl-heptanal 1.4\%, 2-propyl-hexanal $<1 \%$.

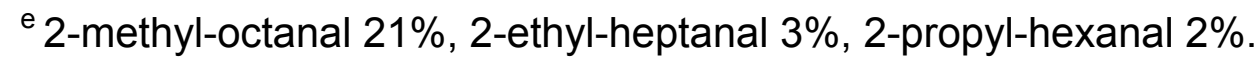


Table 2

Hydroformylation of oct-1-ene by the system $\left[\mathrm{Rh}_{2}\left(\mu-\mathrm{S}_{2} \mathrm{CR}_{2}\right)(\operatorname{cod})_{2}\right] / \mathrm{P}(\mathrm{OMe})_{3}{ }^{a}$

\begin{tabular}{|c|c|c|c|c|c|c|c|}
\hline \multirow[b]{2}{*}{ Run } & \multirow[b]{2}{*}{ Precursor } & \multirow[b]{2}{*}{$\mathrm{P} / \mathrm{Rh}$} & \multirow{2}{*}{$\begin{array}{c}\text { Conversion } \\
\qquad(\%)\end{array}$} & \multicolumn{2}{|c|}{ Selectivity (\%) } & \multirow[b]{2}{*}{$n(\%)$} & \multirow[b]{2}{*}{$\operatorname{TOF}(\text { Ald })^{\mathrm{b}}$} \\
\hline & & & & Ald. & Isom. & & \\
\hline 15 & 1 & 2 & 41.0 & 95.1 & 4.2 & 80 & 117 \\
\hline 16 & 1 & 4 & 53.9 & 97.3 & 2.1 & 81 & 157 \\
\hline 17 & 1 & 6 & 42.0 & 96.9 & 2.6 & 84 & 122 \\
\hline 18 & 2 & 2 & 52.1 & 94.7 & 4.8 & 77 & 148 \\
\hline 19 & 2 & 4 & 67.9 & 97.2 & 2.3 & 81 & 198 \\
\hline 20 & 2 & 6 & 61.2 & 97.6 & 1.9 & 83 & 179 \\
\hline 21 & 3 & 2 & 71.0 & 96.2 & 3.1 & 78 & 205 \\
\hline 22 & 3 & 4 & 75.6 & 96.5 & 2.7 & 80 & 219 \\
\hline 23 & 3 & 6 & 44.5 & 96.3 & 3.2 & 82 & 129 \\
\hline 24 & 4 & 2 & 50.7 & 95.7 & 3.8 & 80 & 146 \\
\hline 25 & 4 & 4 & 84.5 & 96.7 & 2.9 & 80 & 245 \\
\hline 26 & 4 & 6 & 49.3 & 97.8 & 1.9 & 82 & 145 \\
\hline
\end{tabular}

a Reaction conditions: oct-1-ene (1.6 mL, $10.2 \mathrm{mmol}, 0.6 \mathrm{M})$, toluene $(15.4 \mathrm{~mL})$, $\left[\mathrm{Rh}_{2}\left(\mu-\mathrm{S}_{2} \mathrm{CR}_{2}\right)(\mathrm{cod})_{2}\right](0.017 \mathrm{mmol}, 1.0 \mathrm{mM})$, [oct-1-ene $] /\left[\mathrm{Rh}_{2}\right]=600, \mathrm{P}=6.8 \mathrm{~atm}$ $\left(\mathrm{CO} / \mathrm{H}_{2}, 1 / 1\right)$ at $80^{\circ} \mathrm{C}$ for $2 \mathrm{~h}$.

${ }^{\mathrm{b}} \operatorname{TOF}($ Ald $)=\mathrm{mol}$ of aldehyde $[\mathrm{mol} \text { of catalyst }]^{-1} \mathrm{~h}^{-1}$ corresponds to the reaction time $(\mathrm{t})$. 
Table 3

Hydroformylation of oct-1-ene by the system $\left[\mathrm{Rh}_{2}\left(\mu-\mathrm{S}_{2} \mathrm{CR}_{2}\right)(\operatorname{cod})_{2}\right] / \mathrm{PPh}_{3}{ }^{\text {a }}$

\begin{tabular}{|c|c|c|c|c|c|c|c|c|}
\hline \multirow[b]{2}{*}{ Run } & \multirow[b]{2}{*}{ Precursor } & \multirow[b]{2}{*}{$\mathrm{P} / \mathrm{Rh}$} & \multirow[b]{2}{*}{$t(h)$} & \multirow{2}{*}{$\begin{array}{c}\text { Conversion } \\
(\%)\end{array}$} & \multicolumn{2}{|c|}{ Selectivity (\%) } & \multirow[b]{2}{*}{$n(\%)$} & \multirow[b]{2}{*}{ TOF(Ald) } \\
\hline & & & & & Ald. & Isom. & & \\
\hline 27 & 1 & 4 & 6 & 16.7 & 88.8 & 9.2 & 68 & 15 \\
\hline 28 & 1 & 4 & 12 & 93.8 & 93.5 & 6.4 & 75 & 44 \\
\hline 29 & 1 & 6 & 12 & 68.5 & 94.0 & 5.8 & 81 & 32 \\
\hline 30 & 2 & 4 & 2 & 38.4 & 93.2 & 6.5 & 83 & 107 \\
\hline 31 & 2 & 4 & 4 & 40.8 & 90.2 & 9.6 & 75 & 55 \\
\hline 32 & 2 & 4 & 6 & 41.8 & 90.7 & 9.0 & 76 & 38 \\
\hline 33 & 2 & 4 & 12 & 65.2 & 93.2 & 6.3 & 76 & 30 \\
\hline 34 & 3 & 4 & 2 & 46.4 & 90.7 & 8.7 & 74 & 126 \\
\hline 35 & 3 & 4 & 4 & 78.0 & 92.2 & 7.1 & 75 & 108 \\
\hline 36 & 3 & 4 & 6 & 96.1 & 92.3 & 7.2 & 75 & 89 \\
\hline 37 & 3 & 6 & 6 & 96.3 & 92.9 & 5.8 & 80 & 89 \\
\hline 38 & 4 & 2 & 2 & 22.3 & 79.2 & 20.0 & 73 & 53 \\
\hline 39 & 4 & 4 & 2 & 87.4 & 83.7 & 16.2 & 76 & 219 \\
\hline 40 & 4 & 6 & 2 & 70.0 & 91.9 & 7.6 & 76 & 193 \\
\hline
\end{tabular}

a Reaction conditions: oct-1-ene $(1.6 \mathrm{~mL}, 10.2 \mathrm{mmol}, 0.6 \mathrm{M})$, toluene $(15.4 \mathrm{~mL})$, $\left[\mathrm{Rh}_{2}\left(\mu-\mathrm{S}_{2} \mathrm{CR}_{2}\right)(\mathrm{cod})_{2}\right](0.017 \mathrm{mmol}, 1.0 \mathrm{mM})$, [oct-1-ene $] /\left[\mathrm{Rh}_{2}\right]=600, \mathrm{P}=6.8 \mathrm{~atm}$ $\left(\mathrm{CO} / \mathrm{H}_{2}, 1 / 1\right)$ at $80^{\circ} \mathrm{C}$.

${ }^{\mathrm{b}} \mathrm{TOF}(\mathrm{Ald})=\mathrm{mol}$ of aldehyde $[\mathrm{mol} \text { of catalyst }]^{-1} \mathrm{~h}^{-1}$ corresponds to the reaction time $(\mathrm{t})$. 
Table 4

Hydroformylation of oct-1-ene by the system $\left[\mathrm{Rh}_{2}\left(\mu-\mathrm{S}_{2} \mathrm{CR}_{2}\right)(\operatorname{cod})_{2}\right] / \mathrm{PR}_{3}{ }^{\mathrm{a}}$

\begin{tabular}{ccccccccc}
\hline & & \multicolumn{5}{c}{ Conversion } & \multicolumn{2}{c}{ Selectivity (\%) } \\
Run & Precursor & $\mathrm{PR}_{3}$ & $\mathrm{t}(\mathrm{h})$ & $(\%)$ & Ald. & Isom. & $n(\%)$ & TOF(Ald) \\
\hline 41 & 2 & $\mathrm{PCy}_{3}$ & 6 & 20.0 & 100 & - & 57 & 20 \\
42 & 2 & $\mathrm{P}^{\prime} \mathrm{Pr}_{3}$ & 6 & 44.0 & 100 & - & 51 & 44 \\
43 & 2 & $\mathrm{PMe}_{3}$ & 6 & 27.0 & 100 & - & 72 & 27 \\
\hline
\end{tabular}

a Reaction conditions: oct-1-ene $(1.6 \mathrm{~mL}, 10.2 \mathrm{mmol}, 0.6 \mathrm{M})$, toluene $(15.4 \mathrm{~mL})$, $\left[\mathrm{Rh}_{2}\left(\mu-\mathrm{S}_{2} \mathrm{CR}_{2}\right)(\mathrm{cod})_{2}\right](0.017 \mathrm{mmol}, 1.0 \mathrm{mM})$, [oct-1-ene $] /\left[\mathrm{Rh}_{2}\right]=600, \mathrm{P} / \mathrm{Rh}=4, \mathrm{P}=$ $6.8 \mathrm{~atm}\left(\mathrm{CO} / \mathrm{H}_{2}, 1 / 1\right)$ at $80^{\circ} \mathrm{C}$.

${ }^{b} \operatorname{TOF}($ Ald $)=$ mol of aldehyde $[\mathrm{mol} \text { of catalyst }]^{-1} h^{-1}$ corresponds to the reaction time (t). 
Table 5

Hydroformylation of oct-1-ene by the system $\left[\mathrm{Rh}_{2}\left(\mu-\mathrm{S}_{2} \mathrm{CR}_{2}\right)(\mathrm{cod})_{2}\right] / \mathrm{PCy}_{3}{ }^{\mathrm{a}}$

\begin{tabular}{|c|c|c|c|c|c|c|c|}
\hline \multirow[b]{2}{*}{ Run } & \multirow[b]{2}{*}{ Precursor } & \multirow[b]{2}{*}{$t(h)$} & \multirow{2}{*}{$\begin{array}{c}\text { Conversion } \\
\qquad(\%)\end{array}$} & \multicolumn{2}{|c|}{ Selectivity (\%) } & \multirow[b]{2}{*}{$n(\%)$} & \multirow[b]{2}{*}{ TOF(Ald $)^{b}$} \\
\hline & & & & Ald. & Isom. & & \\
\hline 44 & 1 & 12 & 93.1 & 95.9 & 3.0 & 55 & 134 \\
\hline 45 & 2 & 12 & 43.9 & 93.0 & 5.2 & 54 & 61 \\
\hline 46 & 3 & 12 & 71.2 & 96.0 & 3.3 & 55 & 103 \\
\hline 47 & 4 & 12 & 96.9 & 96.4 & 2.5 & 54 & 140 \\
\hline
\end{tabular}

a Reaction conditions: oct-1-ene $(1.6 \mathrm{~mL}, 10.2 \mathrm{mmol}, 0.6 \mathrm{M})$, toluene $(15.4 \mathrm{~mL})$, $\left[\mathrm{Rh}_{2}\left(\mu-\mathrm{S}_{2} \mathrm{CR}_{2}\right)(\mathrm{cod})_{2}\right](0.017 \mathrm{mmol}, 1.0 \mathrm{mM})$, [oct-1-ene $] /\left[\mathrm{Rh}_{2}\right]=600, \mathrm{P} / \mathrm{Rh}=4, \mathrm{P}=$ $6.8 \mathrm{~atm}\left(\mathrm{CO} / \mathrm{H}_{2}, 1 / 1\right)$ at $80^{\circ} \mathrm{C}$.

${ }^{b} \operatorname{TOF}($ Ald $)=$ mol of aldehyde $[\mathrm{mol} \text { of catalyst }]^{-1} \mathrm{~h}^{-1}$ corresponds to the reaction time $(\mathrm{t})$. 
Table 6

Hydroformylation of oct-1-ene by the system $\left[\mathrm{Rh}_{2}\left(\mu-\mathrm{S}_{2} \mathrm{CR}_{2}\right)(\mathrm{CO})_{2}\left(\mathrm{PPh}_{3}\right)_{2}\right] / \mathrm{PPh}_{3}{ }^{\mathrm{a}}$

\begin{tabular}{|c|c|c|c|c|c|c|c|}
\hline \multirow[b]{2}{*}{ Run } & \multirow[b]{2}{*}{ Precursor } & \multirow[b]{2}{*}{$t(h)$} & \multirow{2}{*}{$\begin{array}{l}\text { Conversion } \\
\qquad(\%)^{b}\end{array}$} & \multicolumn{2}{|c|}{ Selectivity (\%) } & \multirow[b]{2}{*}{$n(\%)$} & \multirow[b]{2}{*}{$\operatorname{TOF}(\text { Ald })^{b}$} \\
\hline & & & & Ald. & Isom. & & \\
\hline 48 & 5 & 4 & 15.7 & 89.9 & 9.2 & 75 & 21 \\
\hline 49 & 5 & 12 & 88.2 & 89.9 & 8.0 & 80 & 40 \\
\hline 50 & 6 & 4 & 18.1 & 89.6 & 9.6 & 75 & 24 \\
\hline 51 & 6 & 12 & 68.7 & 92.3 & 6.8 & 74 & 32 \\
\hline 52 & 7 & 4 & 92.7 & 91.8 & 7.7 & 75 & 128 \\
\hline 53 & 8 & 4 & 98.2 & 88.9 & 10.7 & 76 & 131 \\
\hline
\end{tabular}

a Reaction conditions: oct-1-ene $(1.6 \mathrm{~mL}, 10.2 \mathrm{mmol}, 0.6 \mathrm{M})$, toluene $(15.4 \mathrm{~mL})$, $\left[\mathrm{Rh}_{2}\left(\mu-\mathrm{S}_{2} \mathrm{CR}_{2}\right)(\mathrm{cod})_{2}\right](0.017 \mathrm{mmol}, 1.0 \mathrm{mM})$, [oct-1-ene $] /\left[\mathrm{Rh}_{2}\right]=600, \mathrm{P} / \mathrm{Rh}=4, \mathrm{P}=$ $6.8 \mathrm{~atm}\left(\mathrm{CO} / \mathrm{H}_{2}, 1 / 1\right)$ at $80^{\circ} \mathrm{C}$.

${ }^{b} \operatorname{TOF}($ Ald $)=$ mol of aldehyde $[\mathrm{mol} \text { of catalyst }]^{-1} \mathrm{~h}^{-1}$ corresponds to the reaction time $(\mathrm{t})$. 
Table 7

Hydroformylation of trans-oct-2-ene by the system $\left[\mathrm{Rh}_{2}\left(\mu-\mathrm{S}_{2} \mathrm{CBn}_{2}\right)(\mathrm{cod})_{2}\right]$ (3) $/ \mathrm{P}(\mathrm{OPh})_{3}{ }^{\mathrm{a}}$

\begin{tabular}{ccccccccc}
\hline Run & $\mathrm{T}\left({ }^{\circ} \mathrm{C}\right)$ & $\mathrm{P}(\mathrm{atm})$ & $\mathrm{P} / \mathrm{Rh}$ & $\mathrm{t}(\mathrm{h})$ & $\begin{array}{c}\text { Conv. } \\
(\%)\end{array}$ & $\begin{array}{c}\text { Ald. } \\
\text { Selec. }(\%)\end{array}$ & $n(\%)$ & TOF $(\mathrm{Ald})^{\mathrm{b}}$ \\
\hline 54 & 80 & 6.8 & 4 & 18 & 56.0 & 35.0 & 22 & 7 \\
55 & 100 & 6.8 & 4 & 8 & 58.5 & 21.8 & 44 & 10 \\
56 & 100 & 6.8 & 10 & 8 & 79.7 & 46.8 & 41 & 28 \\
57 & 100 & 6.8 & 20 & 8 & 73.3 & 41.2 & 44 & 23 \\
58 & 100 & 2.0 & 10 & 16 & 59.2 & 14.2 & 54 & 3 \\
59 & 100 & 3.4 & 10 & 16 & 75.0 & 31.0 & 51 & 9 \\
60 & 100 & 13.6 & 10 & 8 & 88.1 & 64.1 & 29 & 42 \\
61 & 120 & 6.8 & 10 & 8 & 61.5 & 10.5 & 49 & 5 \\
\hline
\end{tabular}

a Reaction conditions: trans-oct-2-ene (1.6 mL, $10.2 \mathrm{mmol}, 0.6 \mathrm{M})$, toluene $(15.4 \mathrm{~mL})$, $\left[\mathrm{Rh}_{2}\left(\mu-\mathrm{S}_{2} \mathrm{CBn}_{2}\right)(\mathrm{cod})_{2}\right](0.017 \mathrm{mmol}, 1.0 \mathrm{mM})$, [oct-1-ene $] /\left[\mathrm{Rh}_{2}\right]=600, \mathrm{CO} / \mathrm{H}_{2}, 1 / 1$. ${ }^{\mathrm{b}} \mathrm{TOF}(\mathrm{Ald})=\mathrm{mol}$ of aldehyde $[\mathrm{mol} \text { of catalyst }]^{-1} \mathrm{~h}^{-1}$ corresponds to the reaction time (t). 


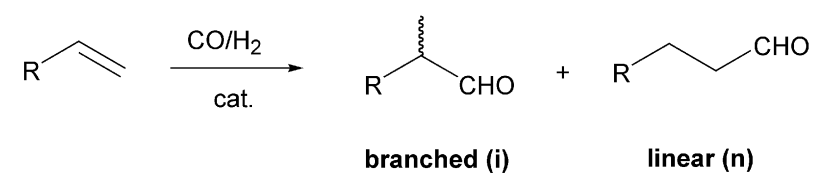

Scheme 1

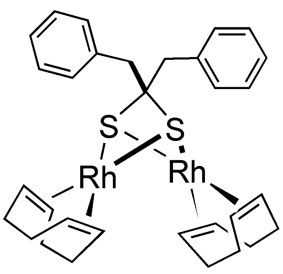

3
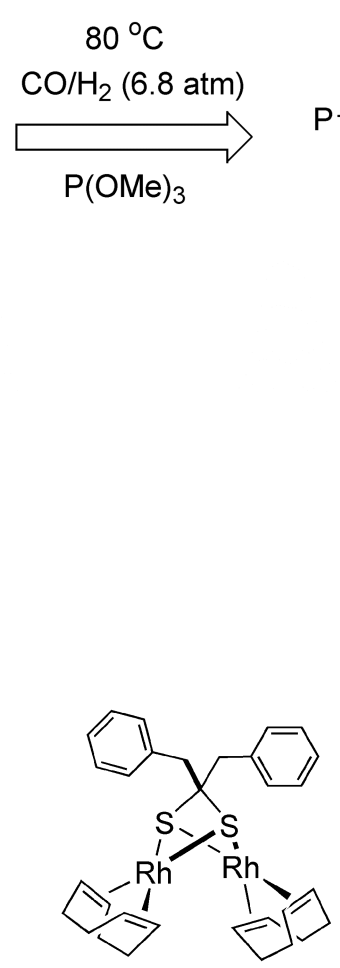

3<smiles></smiles>

9<smiles>O=C1CCCCC1</smiles><smiles>[PH-][P+](P)(P)[PH3-]</smiles>

12<smiles></smiles>

10<smiles></smiles>

11

$$
\mathrm{P}=\mathrm{P}(\mathrm{OMe})_{3}
$$

\section{Scheme 2}
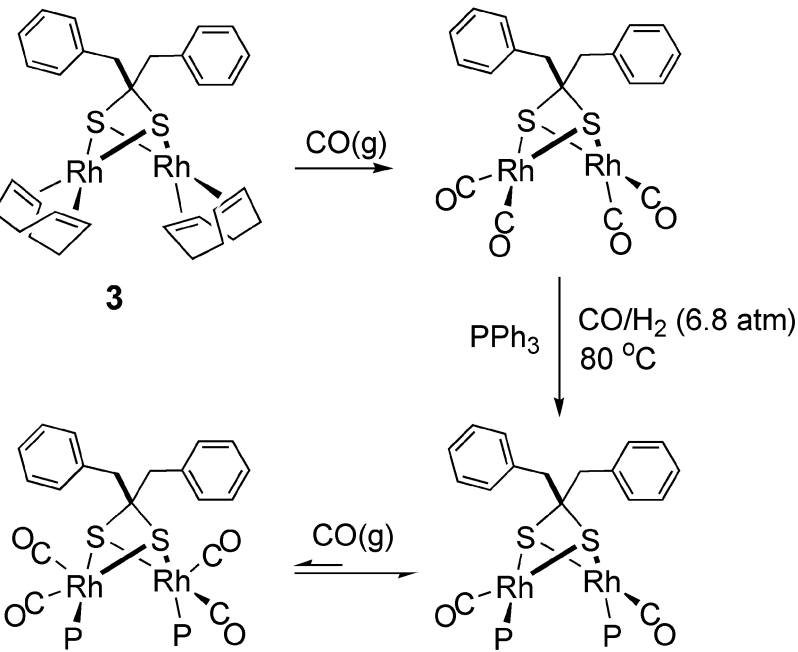

14<smiles>O=C1C=CC=C1</smiles><smiles>SC(S)(Cc1ccccc1)Cc1ccccc1</smiles><smiles>O=P[Pb]1S[SH]2SC1P2P</smiles>

7 $\mathrm{H}_{2}(\mathrm{~g})$

$$
\mathrm{P}=\mathrm{PPh}_{3}
$$<smiles></smiles>

$13 a$<smiles>[1H][PH](=O)([18F])P</smiles>

13b

Scheme 3 


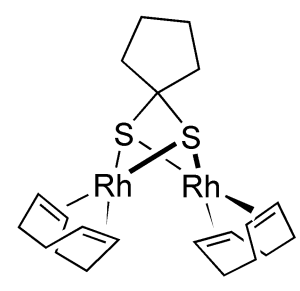

1

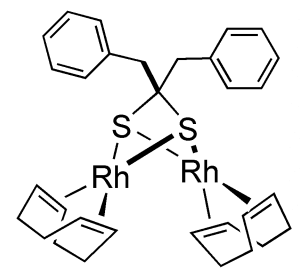

3

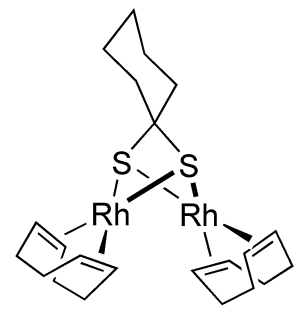

2

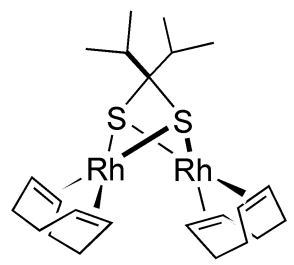

4

Figure 1. Dinuclear gem-dithiolato bridged compounds $\left[\mathrm{Rh}_{2}\left(\mu-\mathrm{S}_{2} \mathrm{CR}_{2}\right)(\mathrm{cod})_{2}\right](\mathbf{1}-\mathbf{4})$ used as catalyst precursors for the hydroformylation of oct-1-ene.

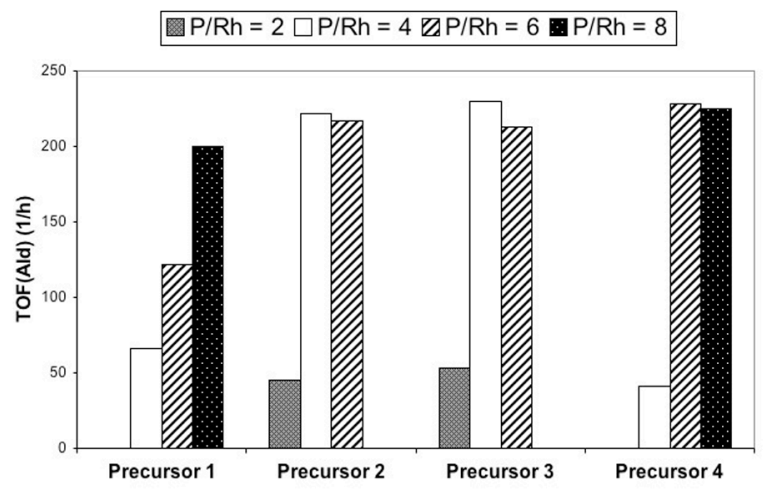

Figure 2. Hydroformylation of oct-1-ene by the systems $\left[\operatorname{Rh}_{2}\left(\mu-S_{2} C R_{2}\right)(\operatorname{cod})_{2}\right](1-$ 4)/ $\mathrm{P}(\mathrm{OPh})_{3}$ : catalytic activity at different $\mathrm{P}(\mathrm{OPh})_{3} / \mathrm{Rh}$ ratios in toluene, at $\mathrm{P}=6.8$ atm $\left(\mathrm{CO} / \mathrm{H}_{2}, 1 / 1\right)$ and $\mathrm{T}=80^{\circ} \mathrm{C}$ for $2 \mathrm{~h}$. 


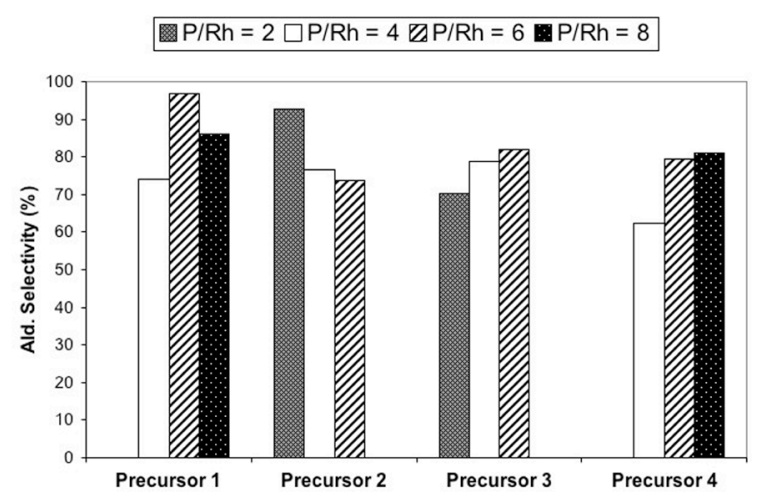

Figure 3. Hydroformylation of oct-1-ene by the systems $\left[\operatorname{Rh}_{2}\left(\mu-S_{2} C R_{2}\right)(\operatorname{cod})_{2}\right](1-$ 4)/ $\mathrm{P}(\mathrm{OPh})_{3}$ : aldehyde selectivity at different $\mathrm{P}(\mathrm{OPh})_{3} / \mathrm{Rh}$ ratios in toluene, at $\mathrm{P}=6.8$ $\operatorname{atm}\left(\mathrm{CO} / \mathrm{H}_{2}, 1 / 1\right)$ and $\mathrm{T}=80^{\circ} \mathrm{C}$ for $2 \mathrm{~h}$.

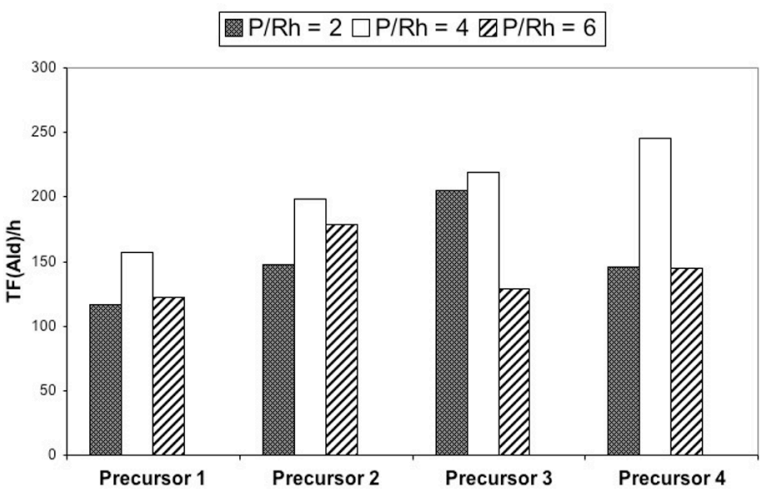

Figure 4. Hydroformylation of oct-1-ene by the systems $\left[\operatorname{Rh}_{2}\left(\mu-S_{2} C R_{2}\right)(\operatorname{cod})_{2}\right](1-$ 4)/ $\mathrm{P}(\mathrm{OMe})_{3}$ : catalytic activity at different $\mathrm{P}(\mathrm{OMe})_{3} / \mathrm{Rh}$ ratios, in toluene at $\mathrm{P}=6.8$ atm $\left(\mathrm{CO} / \mathrm{H}_{2}, 1 / 1\right)$ and $\mathrm{T}=80^{\circ} \mathrm{C}$ for $2 \mathrm{~h}$. 

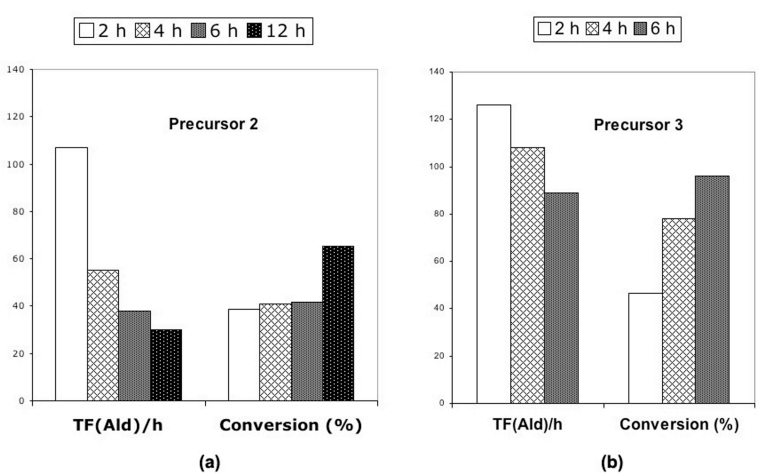

Figure 5. Hydroformylation of oct-1-ene by the systems $\left[\operatorname{Rh}_{2}\left(\mu-S_{2} C h x n\right)(\operatorname{cod})_{2}\right]$ (2)/PPh $/ \mathrm{Pa}_{3}$ and $\left[\mathrm{Rh}_{2}\left(\mu-\mathrm{S}_{2} \mathrm{CBn}_{2}\right)(\mathrm{cod})_{2}\right]$ (3)/ $/ \mathrm{PPh}_{3}$ (b): activity and conversion vs. reaction time at $\mathrm{PPh}_{3} / \mathrm{Rh}=4$, in toluene at $\mathrm{P}=6.8 \mathrm{~atm}\left(\mathrm{CO} / \mathrm{H}_{2}, 1 / 1\right)$ and $\mathrm{T}=80^{\circ} \mathrm{C}$.

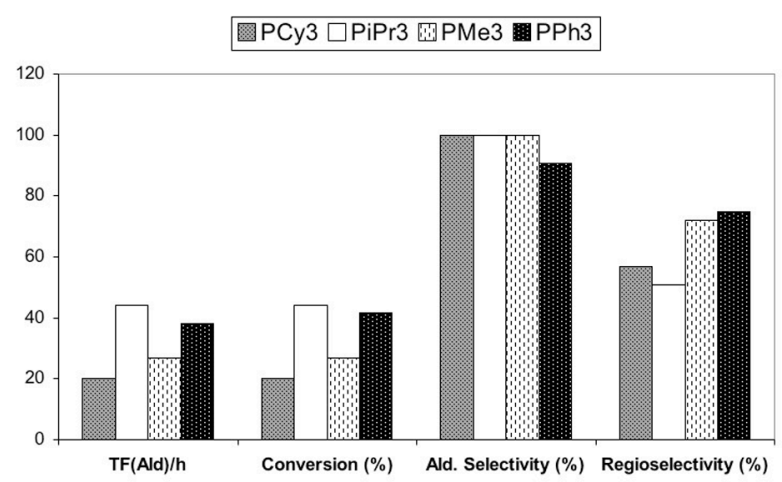

Figure 6 . Hydroformylation of oct-1-ene by the systems $\left[R h_{2}\left(\mu-S_{2} C h x n\right)(\operatorname{cod})_{2}\right]$ (2)/PR $:$ activity, aldehyde selectivity and regioselectivity vs. $\mathrm{PR}_{3}\left(\mathrm{R}=\mathrm{Cy},{ }^{\mathrm{i}} \mathrm{Pr}, \mathrm{Me}\right.$ and $\mathrm{Ph})$ at $\mathrm{PR}_{3} / \mathrm{Rh}=4$, in toluene at $\mathrm{P}=6.8 \mathrm{~atm}\left(\mathrm{CO} / \mathrm{H}_{2}, 1 / 1\right)$ and $\mathrm{T}=80^{\circ} \mathrm{C}$ for $6 \mathrm{~h}$. 


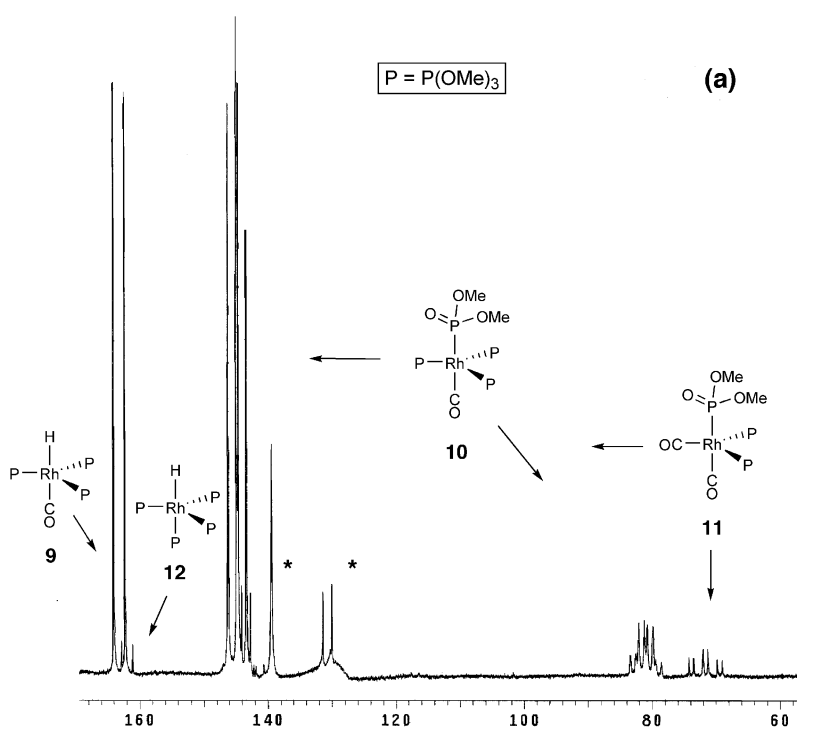

(b)

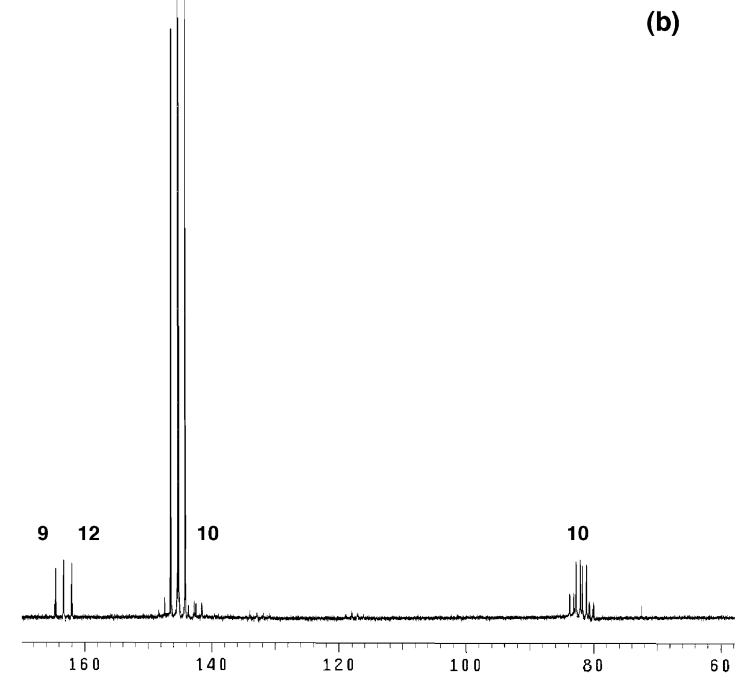

Figure 7. (a) ${ }^{31} P\left\{{ }^{1} H\right\}$ HPNMR (toluene- $\left.d_{8}\right)$ spectrum at $R T$ for the reaction of $\left[R h_{2}(\mu-\right.$ $\left.\mathrm{S}_{2} \mathrm{CBn}_{2}\right)(\mathrm{cod})_{2}$ ] (3) with $\mathrm{P}(\mathrm{OMe})_{3}(\mathrm{P} / \mathrm{Rh}=4$ molar ratio $)$ under 6.2 atm of a $1: 1$ mixture of $\mathrm{H}_{2} / \mathrm{CO}$ after heating for $1 \mathrm{~h}$ at $80^{\circ} \mathrm{C},\left(^{*}\right)$ unidentified species. (b) ${ }^{31} \mathrm{P}\left\{{ }^{1} \mathrm{H}\right\}$ NMR (toluene- $d_{8}$ ) spectrum at RT after depressurization. 


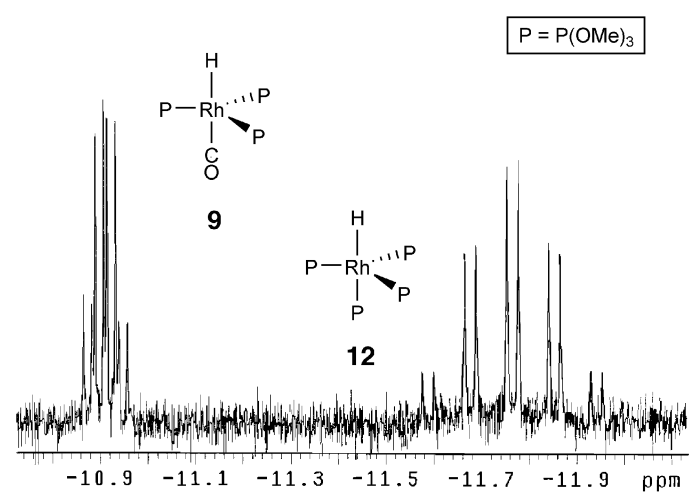

Figure 8. High-field ${ }^{1} \mathrm{H}$ NMR (toluene- $d_{8}$ ) spectrum at RT for the hydroformylation of oct-1-ene catalyzed by $\left[\mathrm{Rh}_{2}\left(\mu-\mathrm{S}_{2} \mathrm{CBn}_{2}\right)(\mathrm{cod})_{2}\right](3) / \mathrm{P}(\mathrm{OMe})_{3}(\mathrm{P} / \mathrm{Rh}=4$ molar ratio $)$ at $80^{\circ} \mathrm{C}$ for $1 \mathrm{~h}$ under $6.2 \mathrm{~atm}$ of a $1: 1$ mixture of $\mathrm{H}_{2} / \mathrm{CO}$ after depressurization.

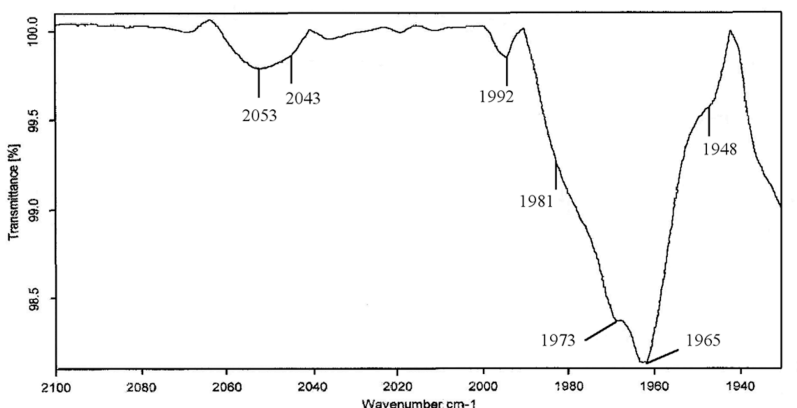

Figure 9. HPIR spectrum for the reaction of $\left[\mathrm{Rh}_{2}\left(\mu-\mathrm{S}_{2} \mathrm{CBn} \mathrm{n}_{2}\right)(\operatorname{cod})_{2}\right]$ and $\mathrm{PPh}_{3}(\mathrm{P} / \mathrm{Rh}=$ 4 molar ratio) in 2-methyltetrahydrofuran under $6.2 \mathrm{~atm}$ of a $1: 1$ mixture of $\mathrm{H}_{2} / \mathrm{CO}$ after $1 \mathrm{~h}$ at $80^{\circ} \mathrm{C}$. 


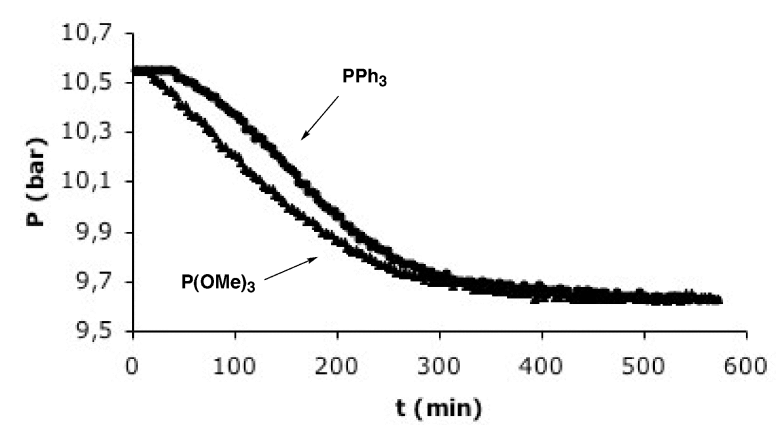

Figure 10. Consumption of $\mathrm{H}_{2} / \mathrm{CO}(\mathrm{g})$ vs time plot for the oct-1-ene hydroformylation by the catalytic systems $3 / \mathrm{P}(\mathrm{OMe})_{3}$ and $3 / \mathrm{PPh}_{3}$ : [3] $=1.35 \mathrm{mM},\left[\mathrm{PR}_{3}\right]=10.8 \mathrm{mM}$ $(\mathrm{P} / \mathrm{Rh}=4$ molar ratio $)$, [oct-1-ene $]=600 \mathrm{mM}, \mathrm{P}\left(\mathrm{CO} / \mathrm{H}_{2}\right)=6.8 \mathrm{~atm}$ and $80{ }^{\circ} \mathrm{C}$.

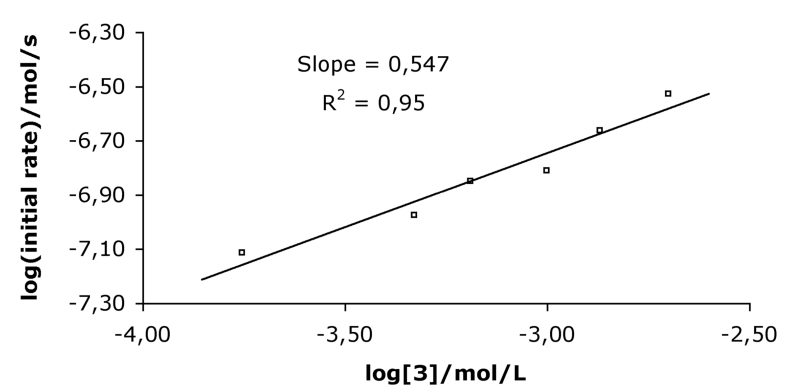

Figure 11. Logarithmic plot for the dependence of initial hydroformylation reaction rate on concentration of precursor 3 in the catalytic system $3 / \mathrm{PPh}_{3}$. [3]: $0.18-2.00$ $\mathrm{mM}, \mathrm{PPh}_{3}(\mathrm{P} / \mathrm{Rh}=4$ molar ratio $)$, [oct-1-ene] $=600 \mathrm{mM}, \mathrm{P}\left(\mathrm{CO} / \mathrm{H}_{2}\right)=6.8 \mathrm{~atm}$ and 80 ${ }^{\circ} \mathrm{C}$ 


\section{Graphic abstract}

Hydroformylation of oct-1-ene catalyzed by dinuclear gem-dithiolato-bridged rhodium(I) complexes and phosphorus donor ligands

Angel B. Rivas ${ }^{b}$, Jesús J. Pérez-Torrente ${ }^{a, ~}{ }^{*}$, Alvaro J. Pardey ${ }^{b, ~}$, Anna M. MasdeuBultó $^{c}$, Montserrat Diéguez ${ }^{c}$ and Luis A. Oro ${ }^{a}$

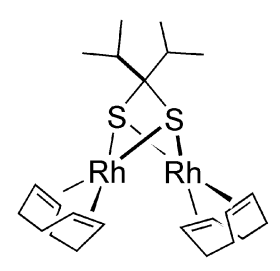

$\mathrm{PR}_{3} / \mathrm{Rh}=\mathbf{4}$

1-octene hydroformylation

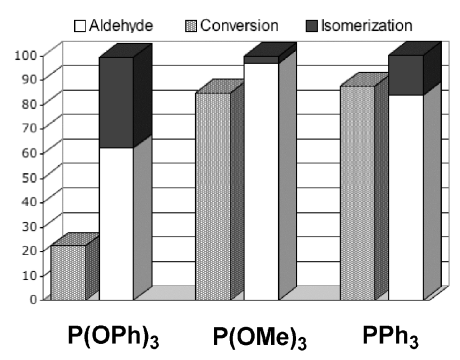

A series of dinuclear compounds $\left[R h_{2}\left(\mu-S_{2} C R_{1} R_{2}\right)(\operatorname{cod})_{2}\right]$ having bridging gemdithiolato ligands $\left(\mathrm{R}^{1}, \mathrm{R}^{2}=-\left(\mathrm{CH}_{2}\right)_{4^{-}},-\left(\mathrm{CH}_{2}\right)_{5^{-}} ; \mathrm{R}^{1}=\mathrm{R}^{2}=\mathrm{Bn},{ }^{i} \mathrm{Pr}\right)$ in the presence of monodentate phosphine or phosphite ligands are efficient catalyst precursors for the hydroformylation of oct-1-ene under mild conditions. The catalytic activity is strongly influenced both by the structure of catalyst precursor and the P/Rh ratio being the precursors containing acyclic gem-dithiolato ligands considerably more active. Spectroscopic studies under pressure showed that mononuclear species formed under catalytic conditions are most likely responsible for the observed catalytic activity. 